\title{
Outward Currents in Isolated Ventral Cochlear Nucleus Neurons
}

\author{
Paul B. Manis and Steven O. Marx ${ }^{\mathrm{a}}$ \\ Departments of Otolaryngology-Head and Neck Surgery, Neuroscience, and Biomedical Engineering, and The Center for \\ Hearing Sciences, The Johns Hopkins University School of Medicine, Baltimore, Maryland 21205
}

\begin{abstract}
Neurons of the ventral cochlear nucleus (VCN) perform diverse information processing tasks on incoming activity from the auditory nerve. We have investigated the cellular basis for functional diversity in VCN cells by characterizing the outward membrane conductances of acutely isolated cells using whole-cell, tight-seal, current- and voltage-clamp techniques. The electrical responses of isolated cells fall into two broad categories. Type I cells respond to small depolarizations with a regular train of action potentials. Under voltage clamp, these cells exhibit a noninactivating outward current for voltage steps positive to $-35 \mathrm{mV}$. Analysis of tail currents reveals two exponentially decaying components with slightly different voltage dependence. These currents reverse at $-73 \mathrm{mV}$, near the potassium equilibrium potential of $-84 \mathrm{mV}$, and are blocked by tetraethylammonium (TEA). The major outward current in Type I cells thus appears to be mediated by potassium channels. In contrast to Type I cells, Type II cells respond to small depolarizations with only one to three short-latency action potentials and exhibit strong rectification around $-\mathbf{7 0} \mathrm{mV}$. Under voltage clamp, these cells exhibit a noninactivating outward current with a threshold near $-\mathbf{7 0} \mathrm{mV}$. Analysis of tail currents reveals two components with different voltage sensitivity and kinetics. A low-threshold current with slow kinetics is partly activated at rest. This current reverses at $-77 \mathrm{mV}$ and is blocked by 4-aminopyridine (4-AP) but is only partly affected by TEA. The other component is a high-threshold current activated by steps positive to $-35 \mathrm{mV}$. This current is blocked by TEA, but not by 4-AP. A simple model based on the voltage dependence and kinetics of the slow low-threshold outward current in Type II cells was developed. The model produces current- and voltage-clamp responses that resemble those recorded experimentally. Our results indicate that the two major classes of acoustic response properties of $\mathrm{VCN}$
\end{abstract}

\footnotetext{
Received Nov. 30, 1990; revised Apr. 22, 1991; accepted Apr. 26, 1991.

We thank Drs. M. B. Sachs and E. D. Young for their valuable comments on the manuscript, and Ms. Diane Kitko for editorial assistance. We are especially grateful to Dr. W. E. Brownell for the loan of the voltage-clamp amplifiers used in the initial experiments and for the use of his osmometer. We are also indebted to Drs. E. Webster (NIDA) and M. Rogawski (NINDS) for insights into procedures for acute cell isolation, and to Dr. D. Bertrand for suggestions on the potassium pharmacology experiments and for his program DATAC. This work was supported primarily by a grant from the Deafness Research Foundation to P.B.M.; additional support was provided by NIDCD Grant DC00425. S.O.M. was supported by NIH Grant T32 NS07283 to Dr. M. B. Sachs.

Correspondence should be addressed to Paul B. Manis, Department of Otolaryngology-Head and Neck Surgery, The Johns Hopkins University School of Medicine, 522 Traylor Research Building, 720 Rutland Avenue, Baltimore, MD 21205.

a Present address: Department of Internal Medicine, University of Rochester School of Medicine, Rochester, NY 14642.

Copyright (C) 1991 Society for Neuroscience $0270-6474 / 91 / 112865-16 \$ 03.00 / 0$
}

neurons are in part attributable to the types of outward (potassium) conductances present in these cells. The lowthreshold conductance in the Type II (bushy) cells probably plays a role in the preservation of information about the acoustic stimulus phase from the auditory nerve to central auditory nuclei involved in low-frequency sound localization.

Neurons of the ventral cochlear nucleus (VCN) receive firstorder input from the auditory nerve (Harrison and Irving, 1966; Feldman and Harrison, 1969; Osen, 1970; Brawer and Morest, 1975; Lorente de No, 1981; Fekete et al., 1984; Rouiller et al., 1986). However, VCN neurons can be distinguished by their discharge patterns in response to acoustic stimuli, suggesting that different classes of cells perform distinct information processing functions on incoming acoustic information (Pfeiffer, 1966a; Bourk, 1976; Young et al., 1988; Blackburn and Sachs, 1989). Some of the different physiological response types are associated with cells of specific morphology (Rhode et al., 1983; Rouiller and Ryugo, 1984; Smith and Rhode, 1987, 1989). Thus, bushy cells, which receive a strong somatic innervation from large endings of auditory nerve fibers (Brawer and Morest, 1975; Fekete et al., 1984), exhibit responses quite similar to those of the auditory nerve. In contrast, stellate cells, which receive both somatic and dendritic innervation by small boutons from auditory nerve fibers (Cant, 1981, 1982), respond to toncs with a regular discharge pattern.

The responses of VCN neurons are also shaped by their intrinsic voltage-dependent conductances (Oertel, 1983; Wu and Oertel, 1984). Bushy cells have been shown to have highly rectifying current-voltage relationships and discharge only one or two action potentials in response to depolarizing current steps. Stellate cells have relatively linear subthreshold current-voltage relationships and discharge a regular train of action potentials in response to current steps. The specific conductances that are responsible for the different discharge characteristics of these two cell classes have not been identified.

In this article, we present the results of voltage-clamp experiments on acutely isolated neurons of the VCN. We find, in agreement with Oertel (1983), that two classes of cells can be identified based on their electrophysiological properties. We then demonstrate that these two classes are distinguished by their different complements of outward currents. The outward currents differ in their voltage dependence, kinetics, and pharmacological sensitivity to potassium channel blockers. A model incorporating the properties of one of the currents in presumptive bushy cells was developed to demonstrate its influence on subthreshold membrane phenomena.

A preliminary report of these results has been presented previously (Manis and Marx, 1989). 


\section{Materials and Methods}

Slice preparation and cell isolation. Tight-seal, whole-cell, voltage- and current-clamp recordings were made from neurons isolated from brain slices of adult guinea pig ventral cochlear nucleus. Slices were prepared following established techniques (Oertel, 1985; Manis, 1989). Pigmented guinea pigs weighing 200-500 gm were deeply anesthetized with pentobarbital $(35 \mathrm{mg} / \mathrm{kg})$ and decapitated with a guillotine. The brainstem was removed from the skull after transecting the eighth nerves. Slices $300-350 \mu \mathrm{m}$ thick were cut either parasagittally or horizontally through the cochlear nucleus with an oscillating tissue slicer. Small pieces of the VCN were excised from the slices with Castroviejo scissors under a dissecting microscope (25-50 $\mathrm{x}$ ). This ensured that isolated cells were obtained only from the $\mathrm{VCN}$, and not from adjoining regions of the brainstem or the dorsal cochlear nucleus. The trimmed slices were incubated in a chamber containing approximately $12 \mathrm{ml}$ of oxygenated dissociation media (see below) at $\sim 34^{\circ} \mathrm{C}$.

The cell isolation procedure was similar to that used for neocortical and brainstem structures (Gray and Johnston, 1985; Kay and Wong, 1986; Numann et al., 1987; Akaike et al., 1988). The slices were treated with a solution that contained, in addition to the basic components listed below, $0.125-0.33 \mathrm{mg} / \mathrm{ml}$ Pronase E (Type XXV, Sigma Chemical Co.) and $0.04-0.08 \mathrm{mg} / \mathrm{ml}$ collagenase (CLS III, Worthington). The slices were treated at $31^{\circ} \mathrm{C}$ for $1 \mathrm{hr}$. During the enzymatic treatment, the slices rested on a nylon net and were slightly agitated by bubbling the solution with $100 \% \mathrm{O}_{2}$. Enzyme activity was terminated by transferring the slices to a solution containing $0.25 \mathrm{mg} / \mathrm{ml}$ soybean trypsin inhibitor (Sigma) and $0.25 \mathrm{mg} / \mathrm{ml} \mathrm{BSA} \mathrm{(Sigma)} \mathrm{for} 5 \mathrm{~min}$ at room temperature. The solution was then changed to one without enzymes, but with added trypsin inhibitor $(0.25 \mathrm{mg} / \mathrm{ml})$ and continuously gassed with $100 \% \mathrm{O}_{2}$ at $22^{\circ} \mathrm{C}$.

Dispersed cells were obtained by gently triturating each slice through a series of three or four fire-polished Pasteur pipettes with gradually decreasing diameters $(2-0.5 \mathrm{~mm})$. The dispersed cells were plated onto pressed (BB Form, Mecanex SA, Geneva, Switzerland) $35 \times 10-\mathrm{mm}$ Petri dishes coated with $10 \mu \mathrm{g} / \mathrm{ml}$ poly-D-lysine (GIBCO Laboratories) to promote adherence (Yavin and Yavin, 1974). After waiting 10-15 min for the cells to attach to the bottom of the dish, a continuous flow $(\sim 0.5 \mathrm{ml} / \mathrm{min})$ was established to clear floating debris and allow substitution of different extraccllular solutions. Slices were viable for at least $10 \mathrm{hr}$, and recordings could be obtained from cells for 2 or more $\mathrm{hr}$ after a selected slice had been triturated.

Solutions. A HEPES-buffered, low-calcium solution was used during slice preparation. This solution contained (in $\mathrm{mM}$ ) $138 \mathrm{NaCl}, 5 \mathrm{KCl}$, 1.25 $\mathrm{KH}_{2} \mathrm{PO}_{4}, 10$ glucose, $10 \mathrm{HEPES}$ (free acid), $0.2 \mathrm{CaCl}_{2}$, and $4 \mathrm{MgSO}_{4}$. The $\mathrm{pH}$ was brought to 7.35 with $1 \mathrm{M} \mathrm{NaOH}$, and the final osmolarity of the solution was approximately $300 \mathrm{mOsm}$. The solution was used at room temperature $\left(\sim 22^{\circ} \mathrm{C}\right)$ and oxygenated with $100 \% \mathrm{O}_{2}$.

The solution used for cell dissociation and recording contained (in mM) $150 \mathrm{NaCl}, 5 \mathrm{KCl}, 10$ glucose, $10 \mathrm{HEPES}$ (free acid), $1.5 \mathrm{CaCl}_{2}, 1.5$ $\mathrm{MgCl}_{2}$, and 1 sodium pyruvate. The $\mathrm{pH}$ was brought to $7.38-7.4$ with $1 \mathrm{M} \mathrm{NaOH}$, and the final osmolarity was $317 \mathrm{mOsm}$. This solution was continuously bubbled with $100 \% \mathrm{O}_{2}$. In some experiments, the recording solution was changed in order to separate components of the whole-cell currents. In such experiments, the osmolarity was maintained at approximately $315 \mathrm{mOsm}$ by reducing the $\mathrm{NaCl}$ concentration. For analysis of tail reversal potentials, extracellular solutions with two different $\mathrm{K}^{+}$concentrations were used. The control solution contained (in $\mathrm{mM}$ ) $130 \mathrm{NaCl}, 20$ choline chloride, $5 \mathrm{KCl}, 10$ glucose, 10 HEPES, $1.5 \mathrm{CaCl}_{2}$, $1.5 \mathrm{MgCl}_{2}$, and 1 sodium pyruvate; $\mathrm{pH} 7.38-7.4$. The high-K ${ }^{+}$solution contained $5 \mathrm{~mm}$ choline chloride and $20 \mathrm{~mm} \mathrm{KCl}$, with all other ingredients the same as the control solution. Potassium currents were blocked with either $4 \mathrm{~mm} 4$-aminopyridine (4-AP) or $20 \mathrm{~mm}$ tetraethylammonium chloride (TEA) substituted in equimolar amounts for $\mathrm{NaCl}$. In some experiments, inward sodium currents were blocked by $1-10 \mu \mathrm{M}$ TTX or complete replacement of sodium chloride with choline chloride. $\mathrm{Co}-$ balt ( $2 \mathrm{~mm}$ ) was also used occasionally to block calcium currents. All salts and pharmacologic agents used in these solutions were purchased from Aldrich or Sigma.

Whole-cell recordings. The isolated neurons were viewed through an inverted microscope equipped with Hoffman modulation contrast optics. Recordings were made using the tight-seal, whole-cell recording method (Hamill et al., 1981) in both current- and voltage-clamp modes. Potash soda-lead glass electrodes (SA-16, Dagan Corp.) were filled with (in mM) $140 \mathrm{KCl}, 0.1 \mathrm{CaCl}_{2}, 1.1$ EGTA, 10 HEPES (free acid), and 2
Mg-ATP. The $\mathrm{pH}$ was brought to 7.2 with $\mathrm{KOH}$, and the final osmolarity was $\sim 270$ mOsm. The resistance of these electrodes in the recording bath was 3-10 M . Seals were obtained by abutting the electrode against the cell membrane and applying gentle suction. The seal resistance before rupture of the cell membrane exceeded $1 \mathrm{G} \Omega$. Trains of action potentials could be observed in some cells before the patch was ruptured.

Amplifiers. Three different amplifiers were used for current- and voltage-clamp recordings from the isolated cells. In the initial experiments, recordings were obtained with a switching amplifier (custom built by Department of Physiology, Centre Medical Universitaire, Geneva; design of D. Bertrand). The relatively large conductance changes that occurred during activation of the outward currents caused the time constants of the cells to fall below $0.5 \mathrm{msec}$, close to the electrode time constants $(\sim 100-500 \mu \mathrm{sec})$. We were thus able to voltage clamp these neurons properly only over the voltage range where the conductance was low (see Finkel and Redman, 1985). The data from these experiments were used only to correlate the threshold voltage for activation of the currents with the properties of the cells as studied in current clamp and to examine the effects of potassium channel blockers on small inward and outward currents.

Most of the quantitative voltage-clamp data reported in this article were obtained either with an Axoclamp-2 amplifier (Axon Instruments) operated in the continuous single-electrode voltage-clamp mode, or with an Axopatch 1C amplifier. Voltage and current records were filtered at $5-10 \mathrm{kHz}$ and digitized at $10 \mathrm{kHz}$ with a 12-bit A-D converter (Manis and Bertrand, 1989). Current records in voltage clamp are averages of four traces. The program DATAC (Bertrand and Bader, 1986) was used for data acquisition, analysis, curve fitting, and plotting.

Series resistance correction. Correction for the voltage drop across the electrode series resistance was important in these experiments. The maximum total current recorded in isolated VCN cells under voltage clamp was in the range of $2-4 \mathrm{nA}$. A current of $4 \mathrm{nA}$ (obtained by stepping the electrode to $+40 \mathrm{mV}$ ) would produce a voltage drop (and hence error in the measured potential) of $40 \mathrm{mV}$ across a $10 \mathrm{M} \Omega$ electrode. This voltage drop is substantial relative to the desired command voltage. We therefore estimated the series resistance and corrected the command voltage to obtain an estimate of the true membrane potential. The actual command voltage was estimated as $V_{c}^{\prime}=V_{c}-I_{m} R_{s}$, where $V_{c}$ is the command voltage, $I_{m}$ is the total current, and $R_{s}$ is the electrode resistance. All command voltages shown were corrected in this manner. Electrode resistance $\left(R_{s}\right)$ was measured during whole-cell recordings from either the peak current (measured in a bandwidth of $20 \mathrm{kHz}$ ) occurring in response to a voltage step $\left(R_{\mathrm{s}}=\Delta V / I_{\text {peak }}\right.$, where $\Delta V$ is the change in potential), or from the charge transferred during the capacitance-charging transient and an estimate of the time constant of the transient decay $\left(R_{s}=\tau \Delta V / Q\right.$, where $\tau$ is the decay time constant and $Q$ is the integrated charge; see Marty and Neher, 1983).

Reversal potentials. Reversal potentials were determined by analysis of tail currents. Outward currents were activated by a $100 \mathrm{msec}$ step to approximately $-10 \mathrm{mV}$. Tail currents were measured during a subsequent $40 \mathrm{msec}$ step to levels between -100 and $-20 \mathrm{mV}$. The tail currents were fit to an exponential function with one or two time constants using a nonlinear (simplex) algorithm. The first $0.5-1.0 \mathrm{msec}$ of the trace, which contains the capacitative charging transient, was omitted from the fits. The instantaneous outward current at the start of the step was then determined by extrapolation of the exponential function to the origin. These data were also used to determine the voltage dependence of the rate constants.

In initial experiments, reversal potentials were recorded in solutions made with glass-distilled water. These were found to be approximately $5 \mathrm{mV}$ positive to those determined from recordings in water purified by ion-exchange columns although all other features of the currents were similar. Ion-selective electrode measurements indicated potassium and calcium ion concentrations in the glass-distilled water of less than 10 $\mu \mathrm{M}$, so it is unlikely that salt contaminants were responsible for this difference. However, reversal potential results are reported only from experiments performed with water purified by ion-exchange methods.

All results are expressed as mean \pm standard deviation, unless otherwise noted.

\section{Results}

The results reported in this article are based on observations made in a total of 123 isolated VCN cells in 77 experiments. Thirty-nine cells were studied only with current clamp. Forty- 

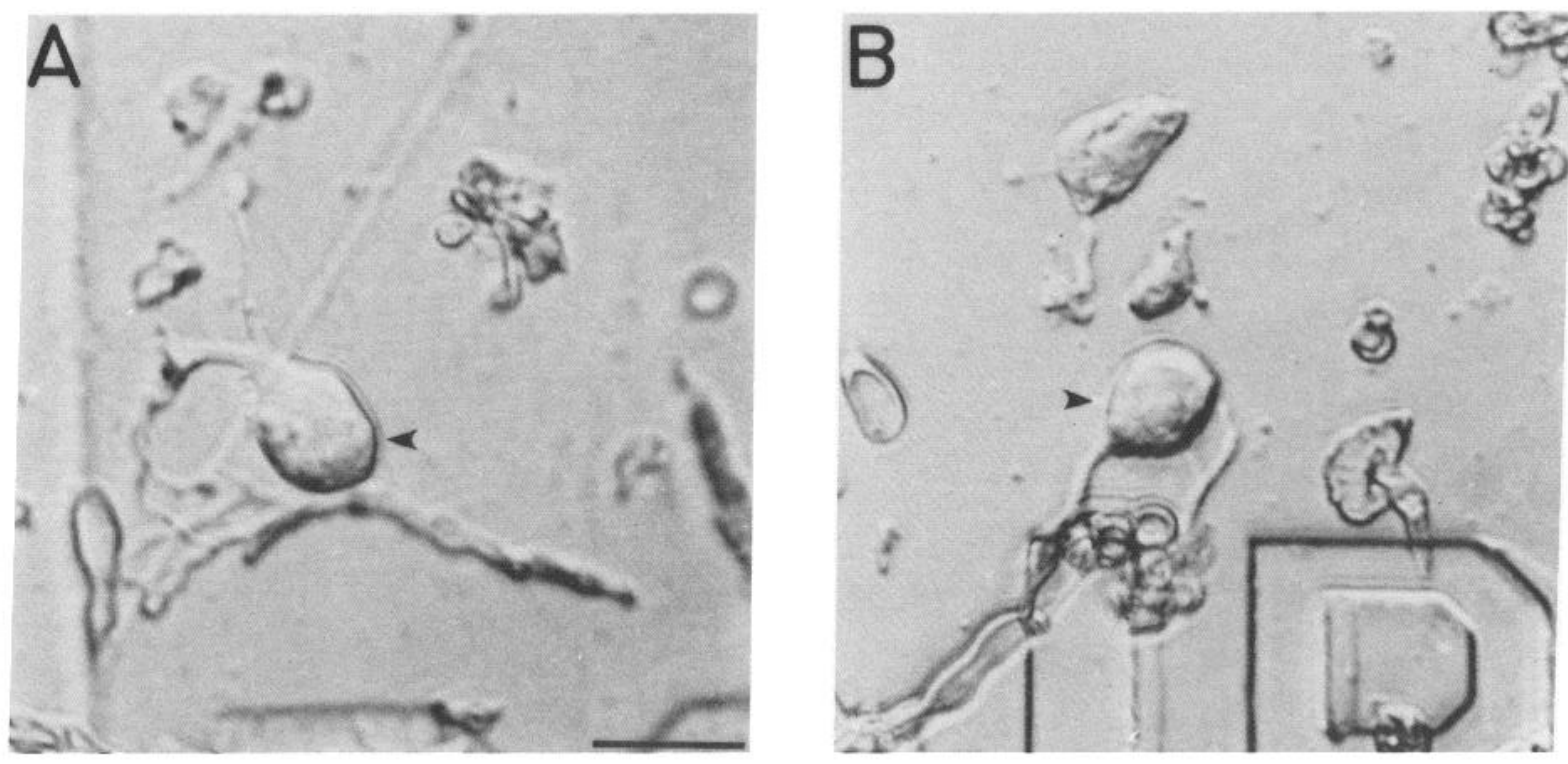

Figure 1. $A$ and $B$, Cells isolated from the guinea pig ventral cochlear nucleus. Cells could be round, ovoid, or polygonal in shape with zero to three short processes. Cells that exhibited smooth membranes and no internal granularity had the best physiologic characteristics (cells indicated by arrowheads). Hoffman modulation-contrast optics, $40 \times, 0.65$ NA. Scale bar, $25 \mu \mathrm{m}$.

four cells were studied under both current and voltage clamp with the switching-type amplifier, but for the reasons outlined in Materials and Methods, the voltage-clamp data from these cells were unsuitable for quantitative analysis. Forty cells were voltage clamped with the nonswitching amplifiers and had data amenable to quantitative analysis.

\section{Isolated cells from the $\mathrm{VCN}$}

Figure 1 shows two isolated cells from the $\mathrm{V} C \mathrm{CN}$. Cells with good appearance, including smooth membranes and a lack of apparent surface roughness or "pits," were found to produce the best recordings. Relatively few such cells were isolated from each slice. Some cells had short processes less than $100 \mu \mathrm{m}$ in length; most had fewer than three processes less than $50 \mu \mathrm{m}$ in length. However, we were unable to determine whether the isolated cells were stellate or bushy cells based on the number of processes or the shape of the cell body. We were also unsuccessful in using morphological criteria to predict the electrical properties of the cells. The only cells that we could identify clearly were granule cells from the lateral margins of the VCN. We excluded granule cells by recording only from cells larger than about $15 \mu \mathrm{m}$ in diameter, such as those shown in Figure 1.

\section{Properties of isolated VCN cells in current clamp}

One hundred and sixteen isolated cells were characterized under current clamp to determine whether the physiological characteristics of VCN neurons described in the brain slice (Oertel, 1983) were retained by the isolated cells. Cells were studied that exhibited action potentials of at least $45 \mathrm{mV}$ when depolarized from $-60 \mathrm{mV}$ and that could be held for at least $5 \mathrm{~min}$. We found two qualitatively distinguishable physiological groups, as shown in Figure 2. One group of cells (46 of 116 cells) fired regular trains of large action potentials (which could overshoot to $+40 \mathrm{mV}$ ) in response to small depolarizing current injections (Fig. $2 A$ ). The action potentials often showed significant height accommodation within a train when large $(>100 \mathrm{pA})$ current steps were used. These cells had relatively high input resistances (determined from the slope of the current-voltage relationship between -60 and $-80 \mathrm{mV})$ of $0.447 \pm 0.265 \mathrm{G} \Omega(N=10$ cells) and exhibited relatively linear current-voltage relationships between -60 and $-90 \mathrm{mV}$ (dashed line in Fig. $2 B$ ). The time constant, measured at rest, was $6.5 \pm 5.7 \mathrm{msec}$. The physiology of this group of cells corresponds well with that of Type I cells (stellate cells) as described in mouse brain slice by Oertel (1983; Wu and Oertel, 1984). Therefore, we will refer to cells with these properties as Type I.

A second population of cells (59 of 116 cells; the remaining 11 cells could not be classified for various reasons) fired only one to three short-latency action potentials at the onset of a depolarizing current pulse (Fig. 2C). The first of these spikes frequently could reach $+40 \mathrm{mV}$, but the remaining spike(s) was usually smaller in amplitude. During the remainder of the current pulse, the membrane potential stayed constant at a voltage less than $20 \mathrm{mV}$ positive to the resting level. After the pulse, the membrane potential often showed a slight undershoot before returning to the resting level. In response to hyperpolarizing current steps, the membrane potential declined rapidly for the first few milliseconds, and for sufficiently large pulses, hyperpolarized slowly for the remainder of the step (Fig. $2 C$ ). In some cases, anomalous rectification was also present during the larger hyperpolarizing steps. After the step, the membrane potential slightly overshot the resting level, resulting in some cases in an anodal break spike (see Fig. $2 C$ ). The input resistance of these cells $(0.225 \pm 0.160 \mathrm{G} \Omega ; N=12)$ was significantly lower than that of the Type I cells ( $p<0.02$ by a two-tailed $t$ test). In addition, these cells had a short time constant for small current pulses $(20-50 \mathrm{pA})$ of $1.69 \pm 0.63 \mathrm{msec}(N=12 ; p<0.02$ compared to the time constant of Type I cells by two-tailed $t$ test). For larger current steps, the membrane potential decayed with additional nonexponential components. Type II cells had nonlinear current-voltage relationships in the region around rest, with outward rectification becoming evident between -60 and $-70 \mathrm{mV}$ (Fig. $2 D$; dashed line indicates linear region between -70 and $-90 \mathrm{mV}$ ). The estimated input resistance of 

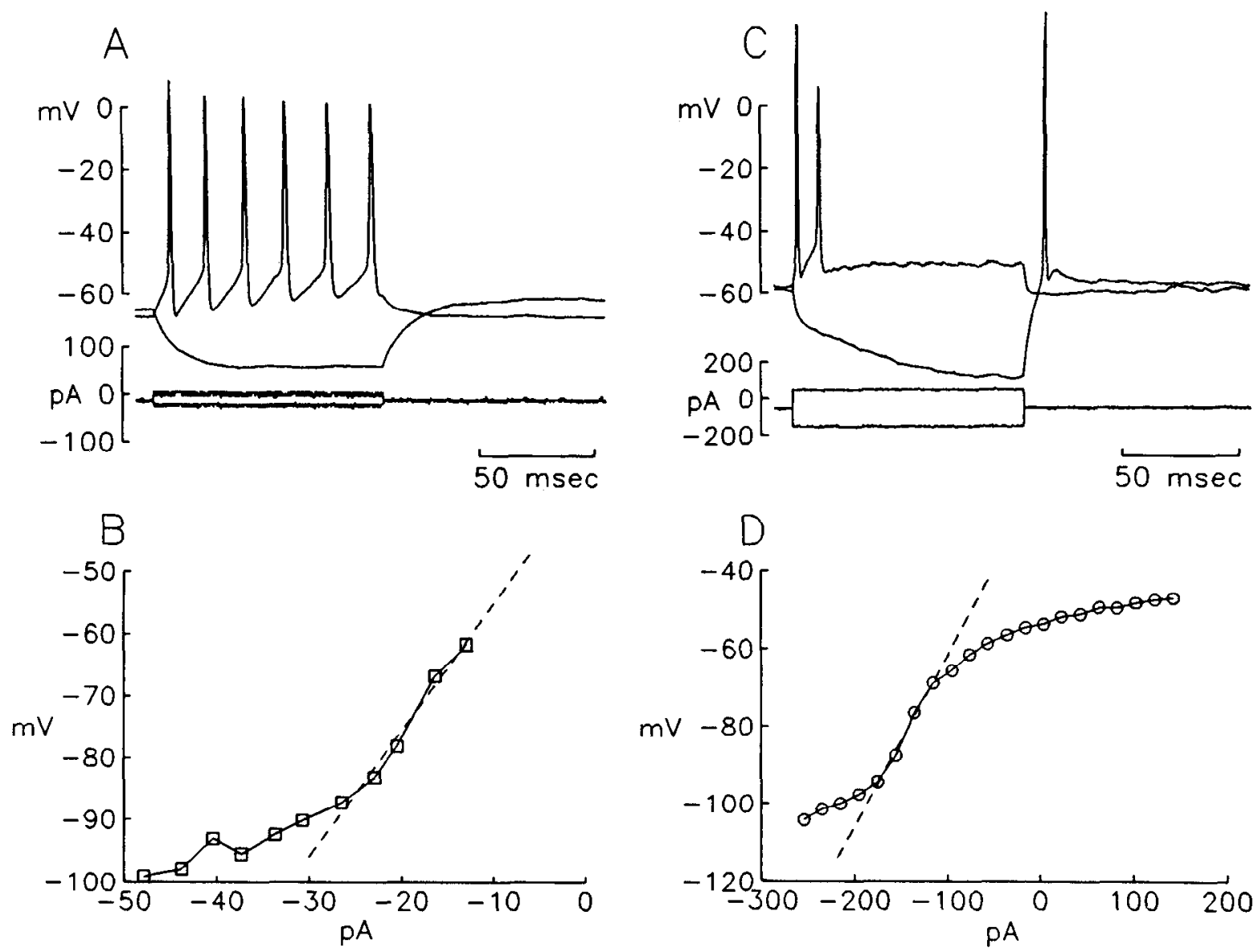

Figure 2. Physiological cell types observed in current clamp. $A$ and $B$, Type I cells are characterized by regular discharge of action potentials in response to small depolarizations and exponential decay of membrane potential in response to hyperpolarization. $B$, The steady-state currentvoltage relationship of Type I cells, measured near the end of the current pulse, is linear below the spike threshold. The dashed line is regression to points between -60 and $-90 \mathrm{mV}$. Anomalous rectification is evident for potentials hyperpolarized to $-90 \mathrm{mV}$. $C$ and $D$, Type II cells are characterized by a phasic discharge of one to three action potentials at all depolarizations and a nonexponential decay of membrane potential to hyperpolarization. A time-dependent anomalous rectification was frequently evident for large hyperpolarizations (not shown). $D$, The steady-state current-voltage relationship for Type II cells, measured near the end of the current pulse, was nonlinear with conductance in the depolarizing direction approximately one-fourth that in the hyperpolarizing direction. The dashed line is a linear regression to the points between -70 and -90 $\mathrm{mV}$. The rectification begins near $-70 \mathrm{mV}$.

Type II cells for depolarizing pulses was $0.053 \pm 0.037 \mathrm{G} \Omega(N$ $=12$ ) or approximately one-fourth of the resistance measured in the hyperpolarizing direction. Cells of this population were similar in their characteristics to the Type II cells in brain slices described by Oertel (1983) and were identified as bushy cells by HRP injection (Wu and Oertel, 1984). We therefore refer to these as Type II cells.

The presence of these two types of physiology in our isolated cells suggests that the cells retain many of their physiological characteristics after the enzymatic treatment and mechanical dispersion. The major differences are the higher input resistances and larger action potentials seen in the isolated cells. The isolated cell preparation is thus suitable for the study of somatic membrane conductances under more controlled conditions than are attainable in the slice. In the remainder of this article, we present the results of voltage-clamp experiments on the outward currents that are the most prominent physiological feature distinguishing these two cell types. Since we were unable to determine cell types from morphology, we initially used the currentclamp responses to classify the cells as Type I or II. In later experiments we were able to determine the cell type from voltage-clamp data alone.

\section{Characteristics of VCN cells under voltage clamp}

Both Type I and Type II cells exhibited inward and outward currents when examined under voltage clamp (see Figs. 3, 6). In normal solutions, a large depolarizing step resulted in an early fast inward current (see insets in Figs. $3 A$ and $6 A$ ) followed by a strong sustained outward current (see traces beneath squares in Figs. $3 A$ and $6 A$ ). The early inward current could be blocked by application of $1-10 \mu \mathrm{M}$ TTX or replacement of the extracellular sodium by choline (not shown), suggesting that it represented a rapidly inactivating sodium conductance. The inward current was not adequately clamped under the conditions of our experiments. ${ }^{1}$ However, since we needed to characterize the cells

\footnotetext{
'As we did not use series resistance compensation for our relatively highresistance electrodes during the experiment, the clamp time constant was slow and varied between 0.1 and $0.5 \mathrm{msec}$ in different experiments (Type I: $316 \pm 75$ $\mu \mathrm{sec}, N=15$; Type II: $238 \pm 20 \mu \mathrm{sec}, N=19$; values expressed as mean $\pm \mathrm{SEM}$ ). Failure to clamp the inward current led to a voltage overshoot at the cell membrane that in turn appeared to activate a fast transient outward current. The outward fast transient appeared to be an artifact for three reasons. First, it did not show sensitivity to 4-AP or prior holding voltage as would be expected of a transient outward current similar to the A-current (Connor and Stevens, 1971). Second, the transient was reduced when TTX or choline was added to block the early
} 
by their discharge patterns under current clamp before examining currents under voltage clamp, we could not routinely use TTX or choline to block the inward currents.

\section{Type I cells}

Type I cells generated a strong outward current that did not show significant inactivation during a $100 \mathrm{msec}$ voltage step (traces beneath square in Fig. 3A). This outward current exhibited a voltage-dependent activation, first appearing for steps in the range of -40 to $-20 \mathrm{mV}$ (Fig. $3 B$ ). Steps to near $0 \mathrm{mV}$ (estimated after correction for the series resistance drop across the electrode) generated outward currents of 2-5 nA. The outward current-voltage relationship was steep (Fig. $3 B$ ). In order to quantify the steady-state conductance, the current-voltage relationship was transformed into conductance using the equation

$$
g(V)=I(V) /\left(V-V_{r}\right),
$$

where $g(V)$ is the conductance (nS), $I$ is the membrane current (pA) at the command voltage, $V$ is the command voltage $(\mathrm{mV})$ after series resistance correction, and $V_{r}$ is the reversal potential for the current. The steady-state conductance relationship could be fit to a Boltzmann function:

$$
g(V)=G_{\max } /\left(1+e^{-\left(V-V_{0.5}\right) z e / R T}\right),
$$

where $G_{\max }$ is the maximal conductance $(\mathrm{nS}), z$ is the equivalent number of gating charges (see Ehrenstein et al., 1974; Hille, $1984), V_{0.5}$ is the half-activation voltage $(\mathrm{mV})$, and $e / R T=0.040$ $\mathrm{mV}^{-1}$ at $22^{\circ} \mathrm{C}$. This function was fit to the data assuming $V_{r}=$ $-73 \mathrm{mV}$ as measured in tail reversal experiments (see below). Fits to the whole-cell conductances in Type I cells resulted in a half-activation voltage of $-8.5 \pm 10.4 \mathrm{~m} \mathrm{~V}$, an equivalent gating valence of $2.94 \pm 1.39$, and a maximal conductance of $39.1+$ $23.7 \mathrm{nS}$ (means $\pm \mathrm{SD} ; N=18$ cells). Because the current-voltage relationships and conductance plots failed to show saturation in the voltage range studied, the maximal conductance estimate represents a lower bound. The half-activation voltage estimate is probably also slightly negative to the actual value; however, because of the steepness of the function the error should be small. Better estimates of the parameters were obtained from the instantaneous current-voltage relationships as described below. The threshold of current activation was estimated from the Boltzmann fit as the voltage at which the conductance was $10 \%$ activated:

$$
V_{0.1}=V_{0.5}-2.917 R T / z e .
$$

For the Type I cells, $V_{0.1}$ was $-30.4 \pm 7.6 \mathrm{mV}(N=18)$.

Type I cell input resistances $\left(R_{\text {in }}\right)$ determined from the steadystate, current-voltage relationship under voltage clamp in the range -60 to $-90 \mathrm{mV}$ were $0.459 \pm 0.372 \mathrm{G} \Omega(N=18$; range, $0.109-1.312 \mathrm{G} \Omega)$. The cell capacitance $\left(C_{m}\right)$, determined from the current required to charge the cell membrane during small hyperpolarizing voltage steps, was $35.0 \pm 25.2 \mathrm{pF}(N=15)$. The time constant $\left(\tau_{m}=R_{\text {in }} \cdot C_{m}\right)$ was $11.3 \pm 9.4 \mathrm{msec}(N=15)$; when one cell with a time constant of $41.4 \mathrm{msec}$ was excluded from this calculation, $\tau_{m}$ was $9.1 \pm 4.5 \mathrm{msec}(N=14)$. These

inward current. Third, a similar transient outward current is generated following the fast inward current when an appropriate series resistance is inserted into a computational model based on Hodgkin-Huxley kinetics (1952). However, transient currents with slower kinetics could be activated when the cell membranc was first hyperpolarized to $-60 \mathrm{mV}$, and these were sensitive to 4-AP (Manis et al., 1991).
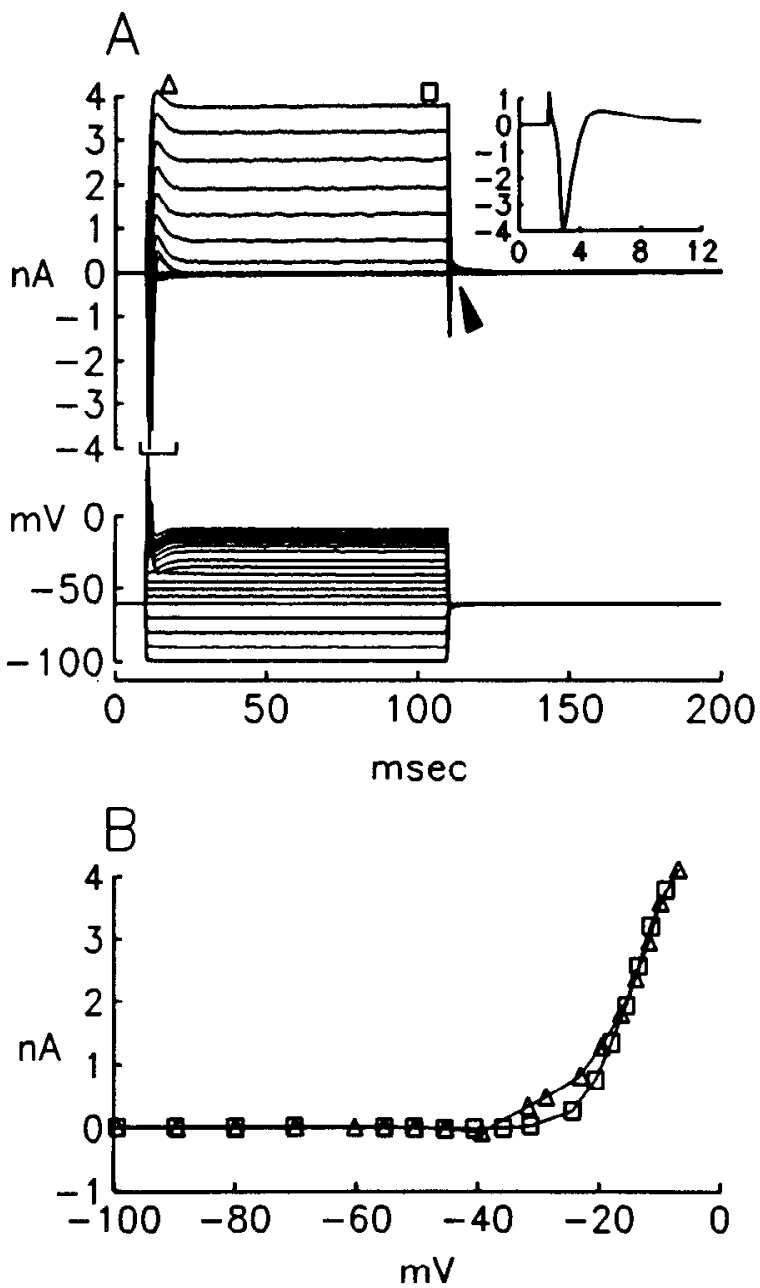

Figure 3. Voltage-dependent currents in Type I cells; traces corrected for leakage conductance (measured between -65 and $-80 \mathrm{mV}$ ) and electrode series resistance. $A$, Time course of currents. Currents shown in top traces, outward or positive current up; command voltages corrected for electrode series resistance drop are shown in lower traces. Depolarization to $-45 \mathrm{mV}$ produces a rapidly activating and inactivating inward current (marked by bar). This current is shown on an expanded time scale in the inset. Steps positive to $-35 \mathrm{mV}$ also produce a noninactivating outward current (below square). A fast transient current (triangle) follows the inward current. $B$, Current-voltage relationships for transient outward current (triangles) and steady-state outward current (squares) measured near the end of the command step. The steady-state outward current becomes strongly activated above -35 $\mathrm{mV}$.

values are not significantly different from those obtained from the current-clamp data.

Tail currents. Tail currents at $-60 \mathrm{mV}$ were evident after the activation of the outward current (Fig. $3 A$, arrowhead; see also Fig. $4 A$ ) when recordings were made in water purified by ion exchange. Tail currents decayed exponentially, with two distinct time constants evident in four of five cells. The presence of two time constants is illustrated in the inset to Figure $4 A$, where the tail currents following steps to two different voltages have been plotted on a semilogarithmic scale. The slow time constant was $12.9 \pm 5.5 \mathrm{msec}(N=5$; but see Discussion), whereas the fast time constant was $1.14 \pm 0.37 \mathrm{msec}(N=4$; the fast component was obscured by a slow capacitance charging transient in the fifth cell) at $-60 \mathrm{mV}$. The existence of two components in the 

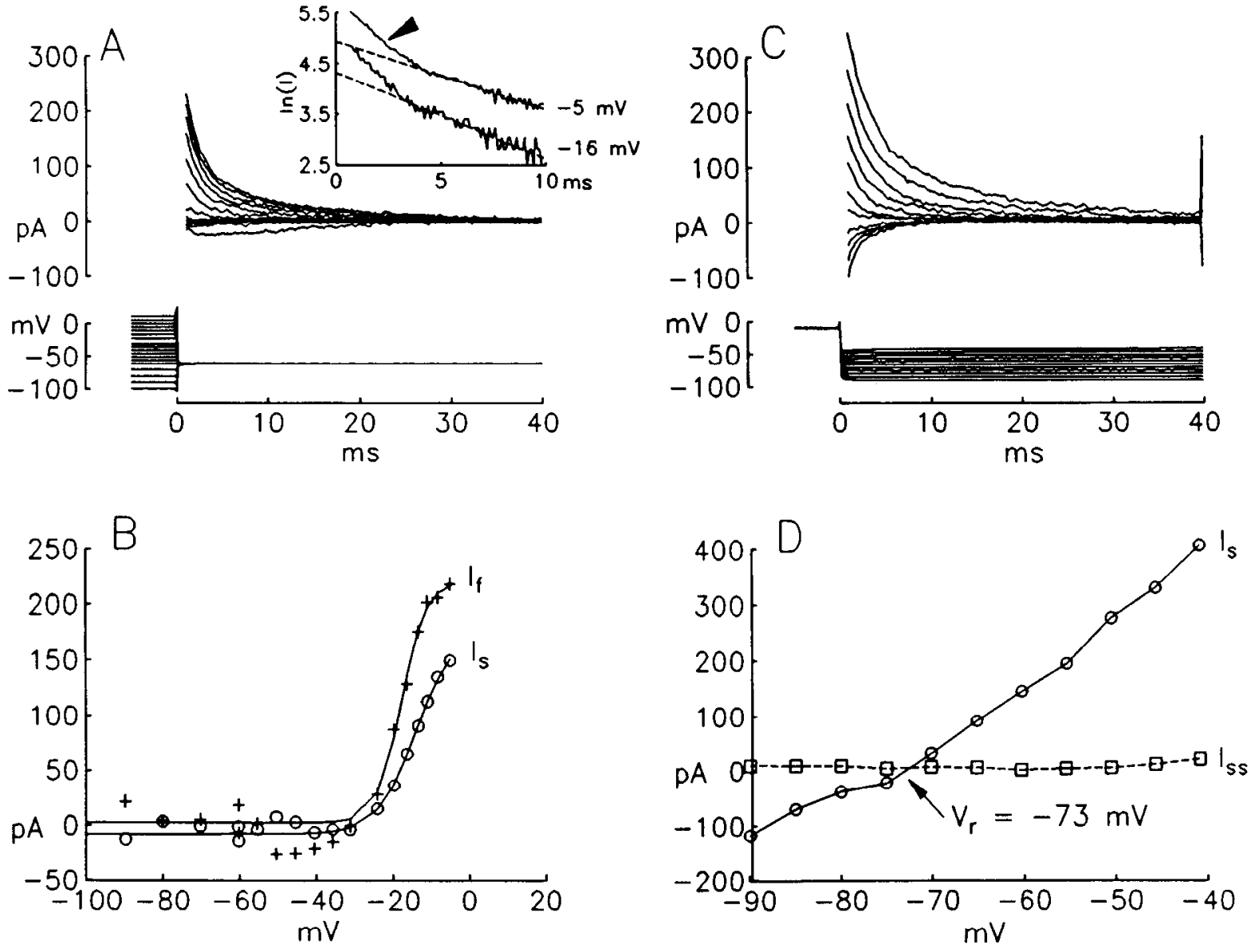

Figure 4. Tail currents in Type I cells. A, Tail currents at $-60 \mathrm{mV}$ following $100 \mathrm{msec}$ duration steps to different levels. Inset shows tail currents on logarithmic scale. Two decay time constants are present both near half-activation threshold $(-16 \mathrm{mV})$ and near maximal activation ( $-5 \mathrm{mV})$. The arrowhead points to a fast component of tail current; dashed line is straight line fit to slow component. $B$, Instantaneous current-voltage relationship estimated from data in $A$ by extrapolating to time 0 the amplitudes of the fast $\left(I_{f},+\right)$ and slow $\left(I_{s}\right.$, O) components that best fit the data in $A$. Both components activate with similar voltage dependence in this cell. Lines through points are Boltzmann function fits to the data. For the fast component, $\tau=1.2 \mathrm{msec}, V_{0.5}=-17.7 \mathrm{mV}$, and $z=7.58$. For the slow component, $\tau=7.8 \mathrm{msec}, V_{0.5}=-14.0 \mathrm{mV}$, and $z=5.0$. $C$, Reversal of tail currents with voltage. Following a $100 \mathrm{msec}$ step to $-10 \mathrm{mV}$, the membrane potential was stepped to voltages between -100 and $-40 \mathrm{mV}$. The currents reverse sign between -75 and $-70 \mathrm{mV}$. The deactivation rate of the current is faster at more negative voltages. $D$, Steady-state current $\left(I_{s s}, \square\right)$ and instantaneous amplitude of slow component $\left(I_{s}, O\right)$. The intersection of the curves (see also Fig. $\left.7 D\right)$ indicates the reversal potential of $-73 \mathrm{mV}$. The instantaneous conductance of the slow component is nonlinear with voltage.

tail currents may indicate that two kinetically distinct outward conductances have been activated during the previous voltage step or that a single conductance with multiple open or closed states was activated. The present data do not distinguish these possibilities. The instantaneous current-voltage relationship was determined by extrapolating the amplitude of each tail current component to the instant of the voltage step as described in Materials and Methods. The resulting activation profile for both the fast and slow currents is similar to that of the steady-state relationship (Fig. $4 B$ ), in that the currents activate near -30 $\mathrm{mV}$ and exhibit a steep activation with voltage. A modified Boltzmann equation was fit to the instantaneous currents:

$$
I(V)=I_{\max } /\left(1+e^{-\left(V-V_{0 . S) z e} R T\right.}\right)+I_{o},
$$

where $I(V)$ is the current at $V, I_{\max }$ is the estimated maximal current, $I_{o}$ is a steady offset current (to account for the fact that the current at the holding potential might not be 0 ), and the other parameters have the same meaning as in Equation 2. Fits of this equation to the instantaneous fast currents resulted in estimates of $-12.6 \pm 8.1 \mathrm{mV}$ for $V_{0.5}$ and $5.5 \pm 2.5$ for $z(N=$
4). The parameters for the slow currents were $V_{0.5}=-24.2 \pm$ $4.3 \mathrm{mV}$ and $z=4.6 \pm 1.2(N=4)$. The $10 \%$ activation thresholds for the two currents were -25.8 and $-40.1 \mathrm{mV}$, respectively. These estimates are probably more reliable than those obtained from the steady-state current-voltage functions because the instantaneous relationships exhibited some saturation of the current.

The reversal potential of the tail currents was measured in three Type I cells following depolarization to approximately $-10 \mathrm{mV}$ (an example is shown in Fig. 4C). Reversal potentials were determined from the intersection of the instantaneous and steady-state current-voltage relationships (determined at the end of the second step, or just prior to the $40 \mathrm{msec}$ time point in Fig. $4 C$ ). As shown in Figure $4 D$, the slow outward current reversed at $-73 \mathrm{mV}$. Similar results were obtained in two other cells $\left(V_{r}=-73 \pm 4 \mathrm{mV} ; N=3\right)$. The fast outward tail current appeared to reverse near the same potential but could not be quantitatively determined because of contamination by the capacitance-charging transient. The reversal potential for both tail decay components is near the theoretical equilibrium potential 
for potassium of $-84 \mathrm{mV}$ calculated from the pipette and bath potassium concentrations. The equilibrium potential for chloride in our recording solutions is $-3.5 \mathrm{mV}$, whereas that for sodium is not well defined due to the lack of added internal sodium but should be positive to $+40 \mathrm{mV}$ according to the amplitude of the action potentials. When the extracellular potassium was changed to $20 \mathrm{mM}$, shifting $E_{k}$ to $-36 \mathrm{mV}$, the tail currents of two cells reversed at -41 and $-42 \mathrm{mV}$. The shift toward the new $E_{k}$ suggests that most of the current is carried by potassium ions. From this analysis, we conclude that the major outward current in Type I cells is mediated by one or two potassium-selective conductances.

Pharmacology of outward currents in Type I cells. As the outward current in Type I cells appeared to be carried by potassium ions, we tested the ability of the potassium channel blockers TEA and 4-AP (Stanfield, 1983; Kolb, 1990) to block the currents. Relatively high concentrations of these agents (20) mM for TEA, $4 \mathrm{~mm}$ for 4-AP) were used in the present experiments in an attempt to produce a complete block of the currents (see also Bader et al., 1985).

In Type I cells, application of $20 \mathrm{~mm}$ TEA almost completely blocked the steady-state outward current for voltages below 0 $\mathrm{mV}$ (Fig. $5 A$ ) and left only a small $(<1 \mathrm{nA})$ current at positive voltages. To quantify the pharmacologic effects, slope conductances were calculated from the mean slope of the currentvoltage relationship over selected voltage ranges. TEA produced a $91 \% \pm 19 \%(N=6)$ reduction of slope conductance over the voltage range between -40 and $-20 \mathrm{mV}$. In a separate population of cells (Fig. $5 B$ ), the application of $4 \mathrm{~mm}$ 4-AP alone produced a $34 \% \pm 46 \%(N=5)$ reduction of the outward current. The combination of $4 \mathrm{~mm}$ 4-AP and $20 \mathrm{~mm}$ TEA resulted in a nearly complete block of the outward currents $(98 \% \pm 9 \% ; N$ $=6$ ), leaving only a small residual current at positive voltages (Fig. $5 A, B$ ). The effects of TEA and 4-AP on the steady-state currents were reversible. These data suggest that the outward current in the Type I cells is primarily carried by a TEA-sensitive conductance similar to the delayed rectifier of other cells. Some component of the conductance is partially and variably reduced by $4 \mathrm{~mm}$ 4-AP (4-AP especially slowed the activation kinetics of the outward current in Type I cells). The pharmacologic experiments were carried out with the cells held at $-68 \mathrm{mV}$ in solutions made with glass-distilled water. Under these conditions, tail currents were small, so we were unable to determine the relative pharmacological sensitivity of the fast and slow tail current components. In the presence of 4-AP and TEA, a sustained inward current was frequently seen between -60 and $-20 \mathrm{mV}$ (arrow in Fig. 5B). This current was not characterized in detail but was blocked by replacement of extracellular sodium with choline (see Manis et al., 1991).

\section{Type II cells}

Type II cells exhibit an early inward current (inset, Fig. 6A) similar to that in Type I cells, and a noninactivating outward current for depolarizing voltage steps (at time marked by square above traces in Fig. 6A). However, in contrast to the Type I cells, the Type II steady-statc current-voltage rclationship reveals outward current that activates between -65 and $-50 \mathrm{mV}$ (Fig. 6B). The outward current exhibits a relatively shallow slope until potentials positive to $-40 \mathrm{mV}$ are reached. Fits of the Boltzmann equation to the whole-cell, steady-state conductance function (derived from Eq. 1, as for Type I cells, but assuming $V_{r}=-77 \mathrm{mV}$; see below) for $18 \mathrm{Type}$ II cells produced estimates
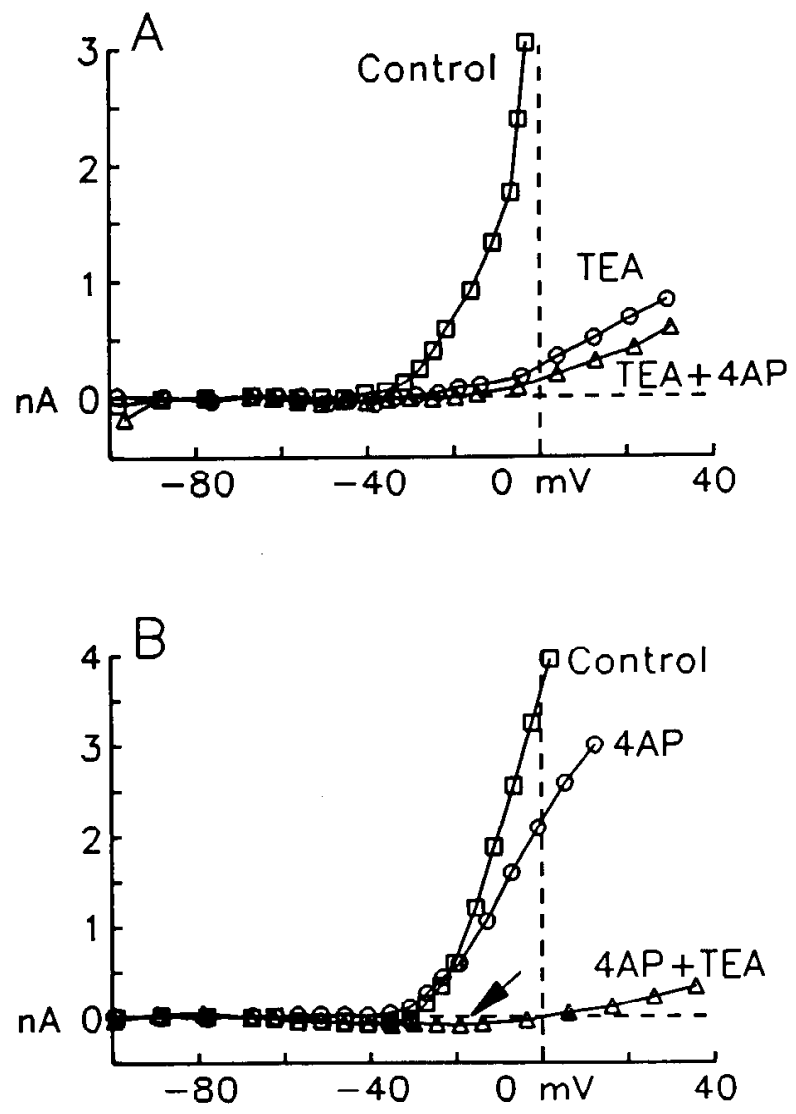

Figure 5. Pharmacology of outward current in Type I cells. Plots show steady-state current-voltage relationships as measured in Figure $3 B . A$, Application of $20 \mathrm{~mm}$ TEA to the cell reduces most of the outward current, leaving a small component activating near $-20 \mathrm{mV}$. The addition of $4 \mathrm{~mm}$ 4-AP to the TEA solution results in a further reduction of the outward current. $B$, Data from a different cell in which the order of drug application was reversed. $4 \mathrm{~mm}$ 4-AP produces a small reduction in the outward current. Subsequent addition of TEA blocks most of the outward current. A small, steady inward current is revealed between 60 and $0 \mathrm{mV}$ (arrow).

of $2.07 \pm 0.77$ for $z,-18.9 \pm 15.2 \mathrm{mV}$ for $V_{0.5}$, and $31.4 \pm$ $15.2 \mathrm{nS}$ for $G_{\max }$. The $10 \%$ activation voltage $\left(V_{0.1}\right)$ for the wholecell conductance was $-48.0 \pm 12.6 \mathrm{mV}$. The values for $z, V_{0.5}$, and $V_{0.1}$ are significantly different from those for Type $I$ cells at the $p=0.02$ level (two-tailed $t$ test). Again, the early inward current in Type II cells was sensitive to TTX or replacement of extracellular sodium by choline. These manipulations, however, did not significantly affect the steady-state outward currents.

The Type II cells also exhibited a small inward transient current in response to hyperpolarizing command steps to potentials below the potassium equilibrium potential (see Fig. 9). Such inward current transients were not present in Type I cells. The transient arose directly out of the capacitative charging current and decayed with a voltage-dependent time constant of 5-10 msec. In addition, at the end of a hyperpolarizing step (returning to $-60 \mathrm{mV}$ ), there was a slow inward current that relaxed with a time constant of $10-20 \mathrm{msec}$ (e.g., Fig. $7 A$ ). Evidence presented below suggests that these current transients are associated with a potassium current in Type II cells.

The input resistance of the Type II cells, estimated from $I_{\mathrm{ss}}$ (steady-state current) between -70 and $-90 \mathrm{mV}$ was $0.162 \pm$ 

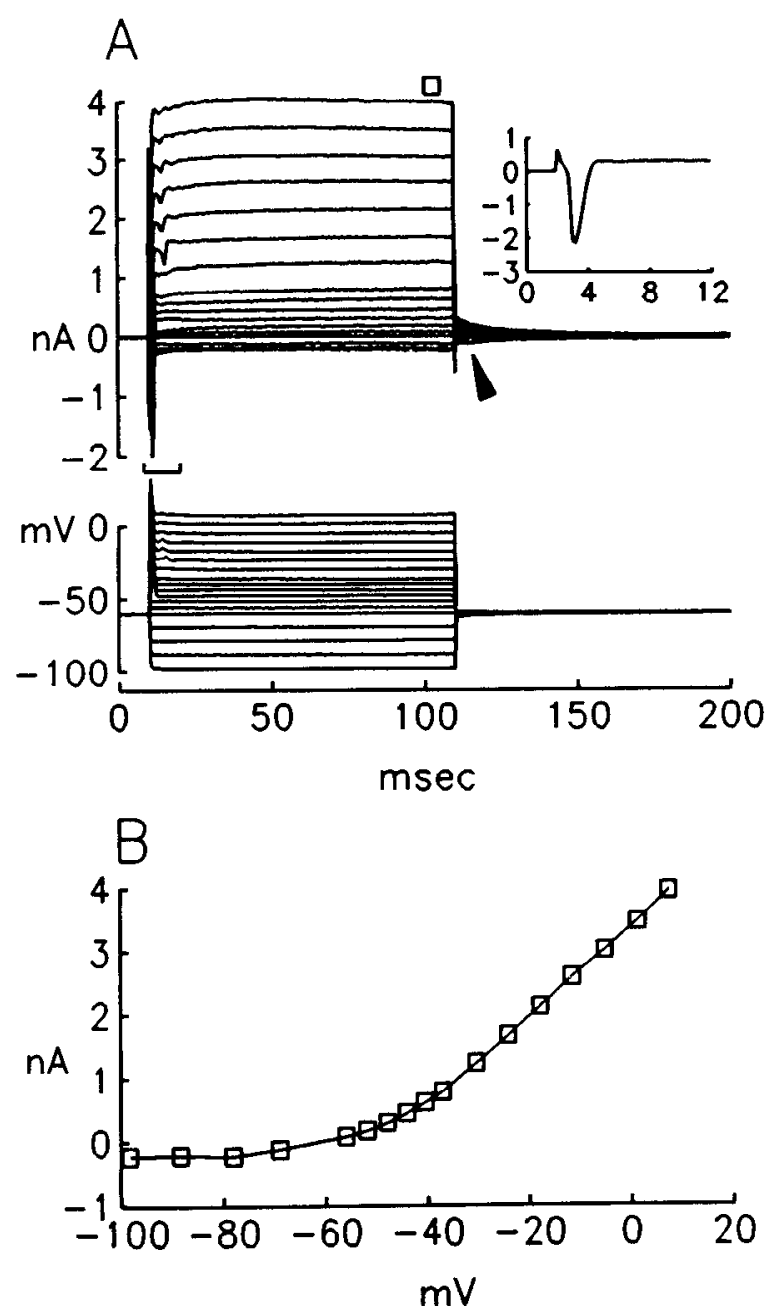

Figure 6. Voltage-dependent currents in Type II cells. Conventions are the same as in Figure 3. $A$, Time course of currents. Depolarization produces a rapidly activating and inactivating inward current (above bar). The inactivating inward current is shown on an expanded time scale in the inset. Steps positive to $-60 \mathrm{mV}$ also produce a noninactivating outward current (e.g., below square). B. Current-voltage relationship for the outward current. The outward current activates near $-70 \mathrm{mV}$.

$0.119 \mathrm{G} \Omega(N=19)$, while the capacitance of these cells was 32.9 $\pm 14.5 \mathrm{pF}$. The membrane time constant for $-10 \mathrm{mV}$ steps from $-60 \mathrm{mV}$ was $4.5 \pm 3.2 \mathrm{msec}$; when one cell with a time constant of $16 \mathrm{msec}$ (greater than $2 \mathrm{SDs}$ from the mean) was excluded the time constant was $3.8 \pm 1.6 \mathrm{msec}(N=18)$. The Type II cells thus exhibited significantly lower input resistances and shorter time constants $(p<0.05$, two-tailed $t$ test) than Type I cells but had similar whole-cell capacitances.

Tail currents. Tail currents during steps to a series of different voltages after a step to near $0 \mathrm{mV}$ are shown in Figure $7 A$ for one Type II cell. Two characteristics of these currents are noteworthy. First, for small depolarizations, the currents decay with a monoexponential time course (semilogarithmic plot in inset, Fig. $7 A,-52 \mathrm{mV}$ ), but for steps to voltages greater than about $-30 \mathrm{mV}$, the decay is best represented by the sum of two exponentials (inset, Fig. $7 A, 0 \mathrm{mV}$ ). The presence of two time constants for steps positive to $-30 \mathrm{mV}$ but only one time constant for smaller steps suggests activation of two distinct currents. The time constant of the fast component at $-60 \mathrm{mV}$ was
$1.61 \pm 0.27 \mathrm{msec}(N=4$ of 6 cells; in one cell the fast component was not evident, and in the other, it was obscured by the capacitative-charging transient), and that of the slow component was $13.0 \pm 1.09 \mathrm{msec}(N=6)$. Second, as mentioned above, there is a slow inward current that also relaxes exponentially after hyperpolarizing steps (Fig. 7A, lowest traces).

The instantaneous amplitude of the fast and slow current components was estimated by extrapolating exponential fits of the tail currents back to the instant of the voltage step. The instantaneous current is plotted in Figure $7 B$ and reveals that the fast component is activated positive to $-30 \mathrm{mV}$, whereas the slow component exhibits voltage-dependent activation between -80 and $-20 \mathrm{mV}$. The activation function for both currents could be well fit by Equation 4 . The slow current had a half-activation voltage of $-53.0 \pm 6.3 \mathrm{mV}(N=6)$ and an equivalent gating valence of $2.38 \pm 0.90$. The total conductance was $14.7 \pm 5.0 \mathrm{nS}$. The fast current activated with a half-activation voltage of $-15.3 \pm 7.8 \mathrm{mV}$, an equivalent gating valence of $4.05 \pm 0.67$, and a total conductance of $7.5 \pm 1.7 \mathrm{nS}(N=$ 4). Thus, as opposed to the two tail components in Type I cells, which had different kinetics but similar voltage dependence, the two tail components in Type II cells had both different kinetics and widely different voltage activation ranges.

Tail currents following a step to approximately $-10 \mathrm{mV}$ were also studied (Fig. 7C). The intersection of the instantaneous and steady-state (measured near the end of the pulse in Fig. 7C) current-voltage relationships indicated a reversal potential for the slow current in three cells of $-77.0 \pm 1.7 \mathrm{mV}$ (Fig. $7 D$ ). As in Type I cells, the amplitude of the fast component could not be reliably determined, but it appeared to reverse near the same potential as the slower current. We also measured the instantaneous amplitude of the slow inward current that occurred following hyperpolarizing steps from $-60 \mathrm{mV}$, since at this potential the conductance appeared to be persistently activated. The mean reversal potential determined in this way was -78 $\pm 5 \mathrm{mV}(N=5$ cells $)$, consistent with the results obtained from the slow component at higher potentials. The mean reversal potential determined by both methods is $-77 \mathrm{mV}$. Again, this reversal potential is far from either the chloride $(-3.5 \mathrm{mV})$ or sodium $(>+40 \mathrm{mV})$ equilibrium potentials but is close to the potassium equilibrium potential $(-84 \mathrm{mV})$, suggesting that this current is mediated by a potassium-selective conductance.

Pharmacology of outward current in Type II cells. As the outward currents in Type II cells appeared to be carried by potassium channels, we again tested TEA and 4-AP for their ability to block currents through these channels. In Type II cells, $20 \mathrm{~mm}$ TEA had a relatively modest effect on the steady-state outward current (Fig. 8A), reducing the slope conductance measured in the range between -60 and $-40 \mathrm{mV}$ by approximately $33 \%( \pm 29 \% ; N=5$ cells). When $4 \mathrm{~mm} 4$-AP was applied alone (Fig. $8 B$ ), the outward conductance in the range between -60 and $-40 \mathrm{mV}$ was reduced by $89 \%( \pm 25 \% ; N=6$ cells $)$, leaving a significant current that activates near $-30 \mathrm{mV}$. However, the combination of $4 \mathrm{~mm} 4-\mathrm{AP}$ and $20 \mathrm{~mm}$ TEA (Fig. $8 A, B$ ) resulted in a nearly complete block of the steady outward current in the voltage range -40 to $-20 \mathrm{mV}(88 \% \pm 34 \% ; N=7$ cells $)$, leaving only a small residual component activated at positive membrane potentials. Because tail currents were small under the conditions used for these experiments, pharmacologic separation of the tail current components could not be performed.

The dual time course of the tail currents (Fig. $7 \mathrm{~A}$ ) and the pharmacologic profile of the steady-state currents (Fig. 8) suggest 

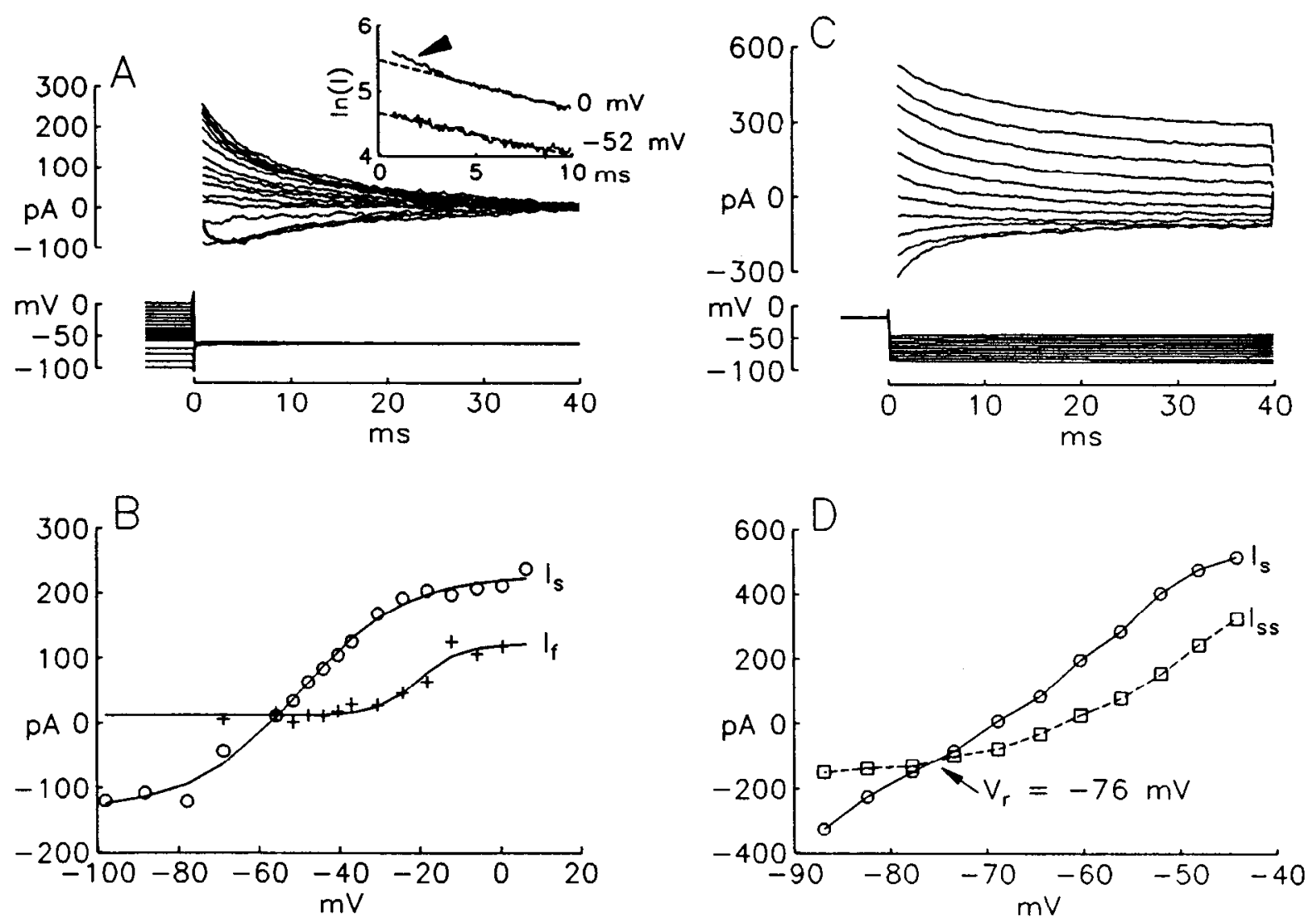

Figure 7. Tail currents in Type II cells. A, Tail currents at $-60 \mathrm{mV}$ following $100 \mathrm{msec}$ duration steps to different levels. Inset shows tail currents on logarithmic scale. Two decay time constants are present near maximal activation $(0 \mathrm{mV})$, but only one is discernable at more negative voltages $(-52 \mathrm{mV})$. The arrowhead points to fast component of tail current; the dashed line is straight line fit to slow component. $B$, Instantaneous currentvoltage relationship estimated from data in $A$ by extrapolating the amplitudes of the fast $\left(I_{f},+\right)$ and slow $\left(I_{\mathrm{r}}, O\right)$ components that best fit the data in $A$. The two components activate with different voltage dependence. Lines through points are Boltzmann function fits to the data (with an additional offset term). For the fast component, $\tau=1.2 \mathrm{msec}, V_{0.5}=-17.7 \mathrm{mV}$, and $z=7.58$. For the slow component, $\tau=13.1 \mathrm{msec}, V_{0.5}=-53.0 \mathrm{mV}$, and $z=2.04$. C, Reversal of tail currents with voltage. Following a $100 \mathrm{msec}$ step to $-10 \mathrm{mV}$, the membrane potential was stepped to voltages between -100 and $-40 \mathrm{mV}$. The currents reverse sign between -75 and $-80 \mathrm{mV}$. The deactivation rate of the current is faster at more negative voltages. $D$, Steady-state $\left(I_{s s}, \square\right)$ current and instantaneous amplitude of slow component $\left(I_{s}, O\right)$. The intersection of the curves indicates the reversal potential of $-76 \mathrm{mV}$. The instantaneous conductance of the slow component is lincar with voltagc.

that Type II cells possess two different kinds of noninactivating outward potassium conductances. One is a low-threshold (activation negative to $-60 \mathrm{mV}$ ), noninactivating conductance that is most sensitive to 4-AP and less sensitive to TEA. This conductance has relatively slow kinetics $(\sim 13 \mathrm{msec}$ at $-60 \mathrm{mV}$, $\left.22^{\circ} \mathrm{C}\right)$. The other conductance has a high threshold $(-40$ to -30 $\mathrm{mV}$ ), is noninactivating, is more sensitive to TEA than 4-AP, and has faster kinetics. This conductance appears similar to the rapidly deactivating conductance seen in the Type I cells.

In order to characterize further the low-threshold conductance, Boltzmann functions were fit to steady-state conductance curves (assuming $V_{r}=-77 \mathrm{mV}$ ) as recorded in the presence of $20 \mathrm{~mm}$ TEA to block the high-threshold conductance. The fits resulted in estimates for $z$ of $1.47 \pm 0.44(N=5), V_{0.5}=-28.0$ $\pm 11.9 \mathrm{mV}$, and $G_{\max }=19.2 \pm 10.4 \mathrm{nS}$. The $10 \%$ activation level was computed to be $-67.9 \pm 4.6 \mathrm{mV}$. These data indicate that this conductance is significantly activated at the resting potential of the cells (i.e., $-60 \mathrm{mV}$ ). These values are somewhat different from the values measured for the slow conductance by tail current analysis in the absence of TEA $\left(V_{0.5}=-53.0 \mathrm{mV}\right.$, $z=2.38, G_{\max }=14.7 \mathrm{nS}$; see above). The differences may be due to a direct effect of TEA on the low-threshold conductance.
The estimates of maximum conductance suggest that the TEAsensitive portion of the conductance only represents $30 \%$ of the total conductance (i.e., about $10 \mathrm{nS}$ ) for membrane depolarizations to near $0 \mathrm{mV}$, consistent with the results from the tail current separation.

The inward transient current observed in response to hyperpolarizing current steps was also examined for its sensitivity to TEA and 4-AP in five cells. In all five cells, this current was abolished with $4 \mathrm{~mm}$ 4-AP, whereas it was little affected by 20 mM TEA (Fig. 9A). The pharmacological profile of this inward transient is thus similar to that of the noninactivating lowthreshold current. It is interesting to note that the changes in the transient inward current and the steady-state outward current with voltage appear to be continuous across the reversal potential (Fig. 9B; the recordings in this experiment were made with glass-distilled water, and the reversal potential was close to the holding potential of $-68 \mathrm{mV}$ ). This observation suggests that the two currents might be manifestations of the same conductance.

Since the low-threshold conductance does not appear to show inactivation and is activated at a membrane potential below $-60 \mathrm{mV}$, cells clamped at $-60 \mathrm{mV}$ will have a steady-state 

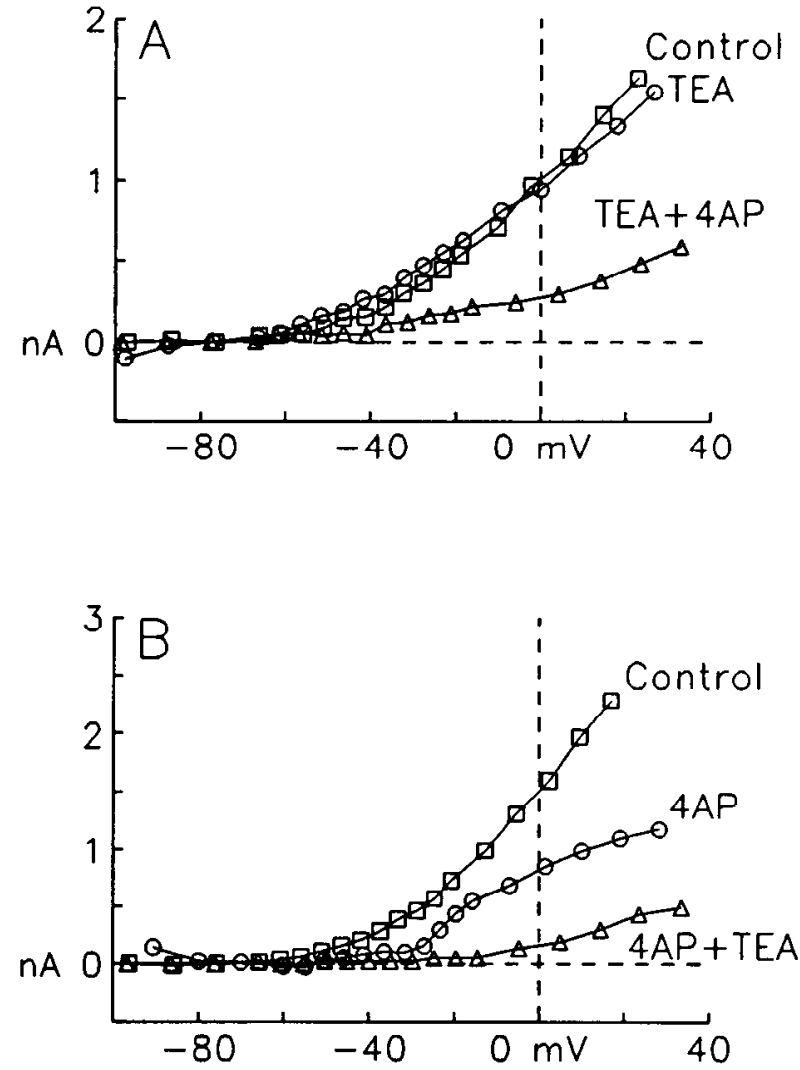

Figure 8. Pharmacology of outward currents in Type II cells. Plots show steady-state current-voltage relationships as measured in Figure $6 B$. A, Application of $20 \mathrm{~mm}$ TEA to the cell has little effect on the outward current. The addition of $4 \mathrm{~mm} 4-\mathrm{AP}$ to the TEA solution results in a partial block of the outward current. $B$, Data from a different cell in which the order of drug application was reversed; $4 \mathrm{~mm}$ 4-AP produces a significant reduction in the outward current for voltage between -70 and $-40 \mathrm{mV}$ but leaves a current that activates positive to -40 $\mathrm{mV}$. Subsequent addition of TEA blocks most of the remaining outward current. current due to conductance through these channels. Hyperpolarizing voltage steps will cause the current to deactivate. When hyperpolarizing steps are made to a membrane potential below the reversal potential of the current, an inward current relaxation occurs. Following return to the holding potential from a hyperpolarized potential, the current slowly reactivates, resulting in the transient inward current seen in the tail current analysis (Fig. 7).

\section{Kinetics of low-threshold conductance in Type II cells}

The kinetics of low-threshold current activation and deactivation were investigated in Type II cells. In order to minimize the contributions from other conductances, kinetic measurements were made from cells recorded in the presence of TTX, or in medium with sodium replaced by choline to block sodium currents, or from the slow component of the tail currents following steps to $-10 \mathrm{mV}$. In two cells, activation kinetics were determined from recordings in choline plus TEA for steps up to -20 $\mathrm{mV}$. In the presence of TTX or choline, activation of the current was adequately fit by a single exponential function for voltage steps from -60 to $-30 \mathrm{mV}$ and showed no delay (not shown). Deactivation of the current was determined from two different protocols. First, the time constant of the slow exponential decay that followed steps to $-10 \mathrm{mV}$ was analyzed as a function of voltage, using the protocol in Figure $7 \mathrm{C}$. Second, the rate of deactivation of the inward current seen with large hyperpolarizing steps from -60 or $-68 \mathrm{mV}$ (as in Fig. 9A) was measured. The equations used to model the conductance are described in the Appendix.

The experimentally determined time constants $\tau_{B}(V)$ (Eq. A5) are shown in Figure $10 \mathrm{~A}$ for voltages between -100 and -20 $\mathrm{mV}$. The time constants are voltage dependent with a maximum near $-60 \mathrm{mV}$ and slightly faster values at more positive and more negative voltages. The steady-state activation function $B_{B(\infty)}$ (Eq. $\left.\Lambda 6\right)$ was approximated using the Boltzmann description from the instantaneous tail currents (with $V_{0.5}=-53.3 \mathrm{mV}$, gating charge of 2.38; data from analysis as in Fig. 7) and was
Figure 9. Pharmacology of inward relaxation in Type II cells. $A$, Inward current tails in different solutions following a step to $-100 \mathrm{mV}$ from holding potential of $-68 \mathrm{mV}$. The tail is present in normal and TEA-containing solutions but is blocked when 4-AP is added to the TEA solution. Arrowheads indicate the times used for analysis of transient current and steady-state current amplitudes in $B$ and $C$. $B$, Transient current measured at the time indicated by arrowhead $B$ in $A$ as a function of command step voltage from a holding potential of $-68 \mathrm{mV}$. TEA (triangles) has little effect on the current; the addition of 4-AP $(+)$ blocks the current leaving only a linear leak component. $C$, Steady-state currents measured at the time indicated by $a r$ rowhead $C$ in $A$ for steps to various voltages. TEA (triangles) has little effect on the outward current that activates near $-65 \mathrm{mV}$, whereas 4-AP $(+)$ blocks the outward current.
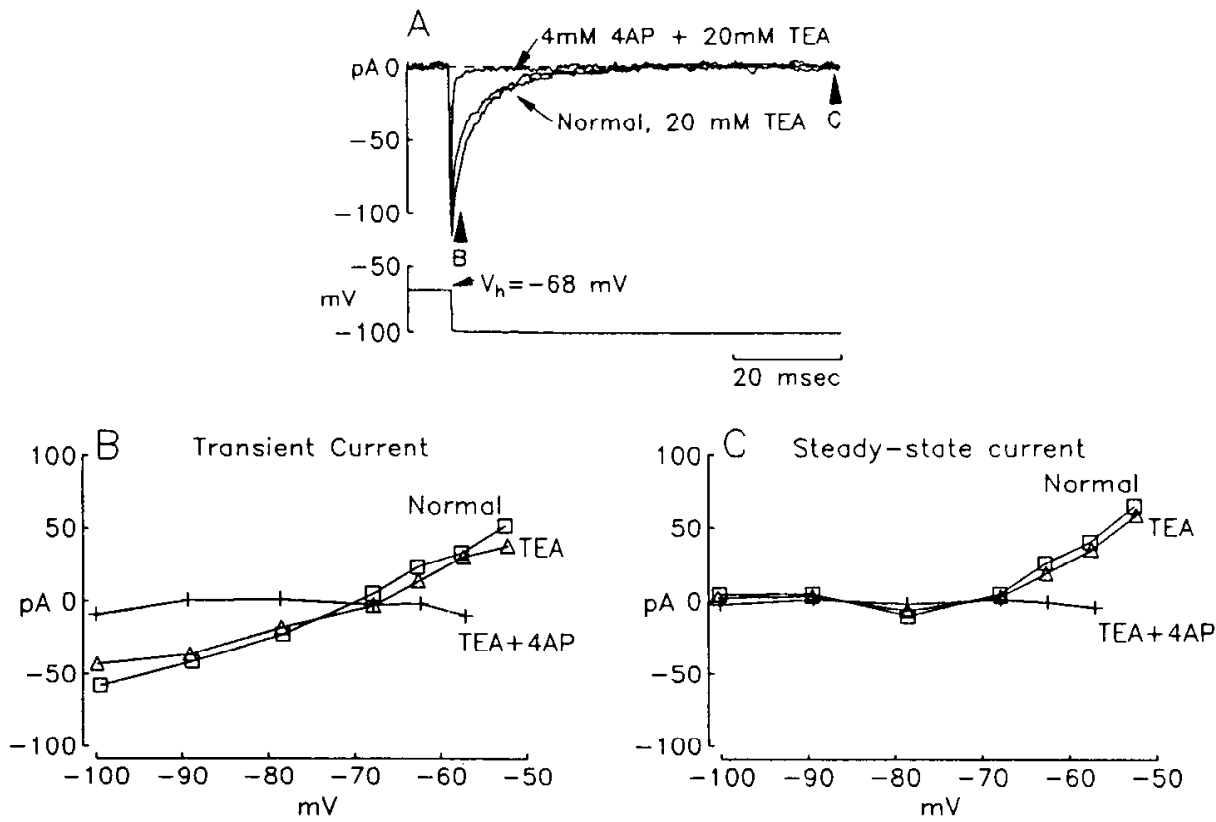
substituted for $B_{B(\infty)}(V)$ in Equations $A 7$ and $\Lambda 8$. The resulting rates $\alpha_{B}(V)$ and $\beta_{B}(V)$ are plotted as squares and triangles, respectively, in Figure $10 \mathrm{~B}$. The separated rate estimates were then fit using a nonlinear simplex algorithm to exponential functions of voltage for $\alpha_{B}$ and $\beta_{B}$ (Eqs. A3, A4). During the fitting process, it was found that the value of $V_{O}$ was not well determined, so it was fixed at $-53.3 \mathrm{mV}$, the half-activation voltage determined from the Boltzmann description of the activation profile. The resulting rate constants and slope factors are $\alpha_{B}(0)$ $=0.030 \mathrm{msec}^{-1}, K \alpha=0.069 \mathrm{mV}^{-1}, \beta_{B}(0)=0.042 \mathrm{msec}^{-1}$, and $K \beta=0.032 \mathrm{mV}^{-1}$. These values are clearly approximate because of the scatter in the data. The resulting fitted descriptions of $\alpha$ and $\beta$ are shown in Figure $10 B$ with dashed lines. The inset shows that the equivalent steady-state activation function $B_{B(\infty)}$ (from Eq. A6) is similar to the Boltzmann function describing the experimental data, although the voltage dependence was shifted slightly in the positive direction. The difference between the curves represents errors in the parameter estimates accumulated during the fitting procedure. Thus, the rate functions $\alpha_{B}$ and $\beta_{B}$, along with Equation 4 , appear to describe adequately the voltage- and time-dependent behavior of the low-threshold conductance.

The behavior of a simple model cell containing only the lowthreshold conductance, with leak and capacity currents, was investigated. The current through the cell was described as

$$
I_{m}=C_{m} \frac{d V}{d t}+G_{B \max } B_{b}\left(V-V_{b}\right)+G_{l}\left(V-V_{l}\right)
$$

where $C_{m}$ is the membrane capacitance $(32.9 \mathrm{pF}), G_{B_{\max }}$ is the maximal conductance of the low-threshold conductance $(20 \mathrm{nS})$, $G_{l}$ is the leak conductance $(2.5 \mathrm{nS}), V_{B}$ is the reversal potential for the low-threshold conductance $(-77 \mathrm{mV})$, and $V_{l}$ is the reversal potential for the leak conductance (assumed to be -10 $\mathrm{mV}$ ). These parameters predict a cell with a resting potential of $-57.7 \mathrm{mV}$, an input resistance at rest of $0.059 \mathrm{G} \Omega$, and a time constant $\tau_{m}$ of $1.94 \mathrm{msec}$. Except for the low input resistance of the model cell (measured from the tangent to the current-voltage relationship at rest; the input resistance is higher when measured between -60 and $-70 \mathrm{mV}$ ), these values are similar to the values measured in the isolated cells under current clamp.

Time domain responses were obtained by integrating Equation 5 using a fourth-order Runge-Kutta algorithm with 20 $\mu$ sec steps. The response of the model cell to voltage steps in voltage clamp is shown in Figure $11 \mathrm{~A}$ (after subtraction of leak currents). The model predicts the transient inward current (solid arrowhead) and the slow return of the current to the resting level following hyperpolarizations (open arrowhead). The model also has kinetics similar to those seen in the isolated Type II cells. The instantaneous current-voltage relationship computed from the model tail currents is shown in Figure $11 B$. The activation range of the low-threshold conductance is similar to the experimental range (compare with Fig. $8 B$ ). The dashed line through the points is a Boltzmann equation fit to the model; values of -49.5 for $V_{0.5}$ and 2.5 for $z$ were obtained from the fit, similar to the observed values. These results verify that the kinetic model adequately describes the low-threshold conductance in the Type II cells.

The model was then computed in current clamp (Fig. 11C). The model cell shows strong rectification around rest (equal but opposite current steps produce quite unequal voltage excursions). Time-dependent changes in the voltage due to the low-
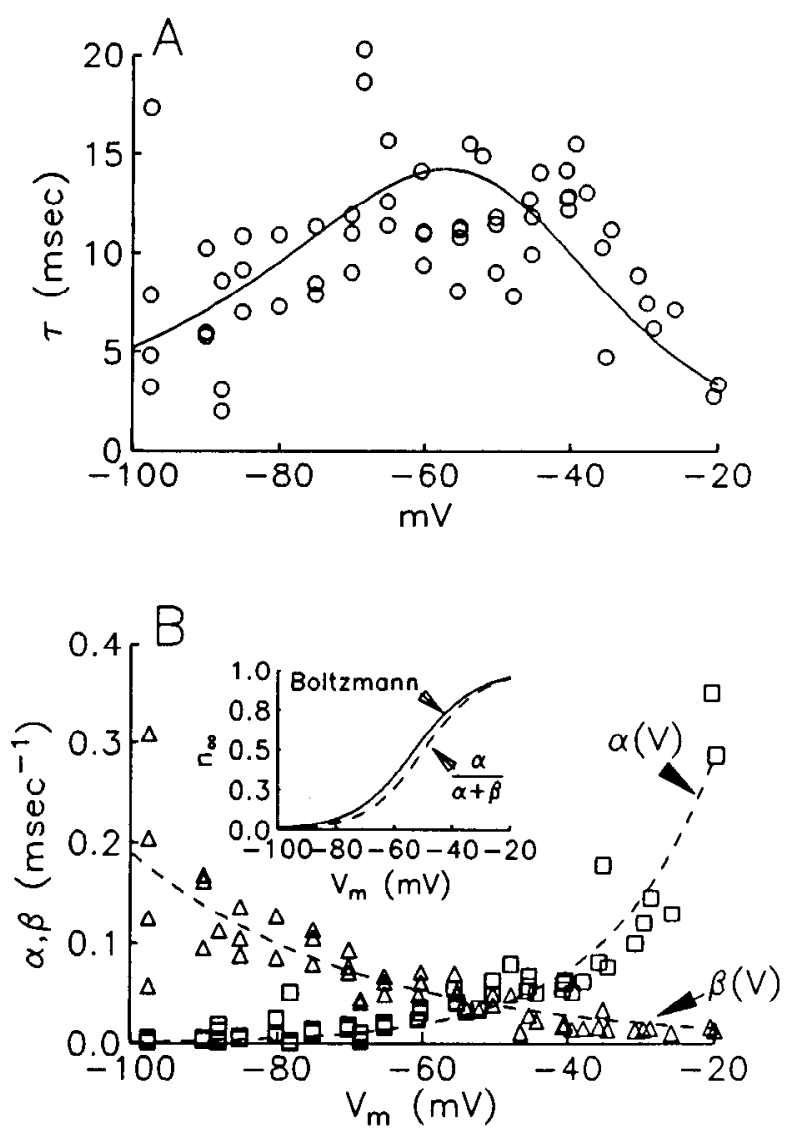

Figure 10. Kinetics of low-threshold outward current in Type II cells. $A$, Time constants of activation and deactivation of current as a function of voltage (circles); pooled measurements from five cells. Line through points is fit of data to Equation A5 (see Appendix). B, Activation $[\alpha(V)$, squares] and deactivation $[\beta(V)$, triangles] rate constants as a function of voltage. Dashed lines through points are fits to Equations A3 and A4 in Appendix. Inset, Comparison of Boltzmann activation function determined from instantaneous activation curves (solid line) and steadystate activation function $B_{b}$ determined from Equation $\mathrm{A} 6$ (dashed line).

threshold conductance are visible. Depolarizations produce a hump followed by a sag to a steady level. The sag results from activation of the low-threshold conductance. At the offset of the depolarizing step, the cell shows a rapid return toward the resting potential with a slight undershoot. For hyperpolarizing steps, shape of the response depends on the magnitude of the injected current. For small currents, there is a slight sag back toward the resting potential after an early peak, reflecting the deactivation of the low-threshold conductance and movement toward the leak reversal potential. For larger steps, the potential decay is nonexponential with fast and slow components. The slow component reflects the further deactivation of the low-threshold conductance, whereas the fast component is governed by the cell time constant at rest (before the conductance changes significantly). At the offset of the hyperpolarizing pulse, there is a brief overshoot before the cell settles back to the resting potential. The overshoot occurs because the low-threshold conductance has deactivated during the hyperpolarization and takes some tens of milliseconds to reactivate fully. The overshoots and undershoots in the voltage response are frequently visible in the responses of Type II cells both in isolated cells (Fig. 2) and in the slice (see Oertel, 1983). It appears that these features 

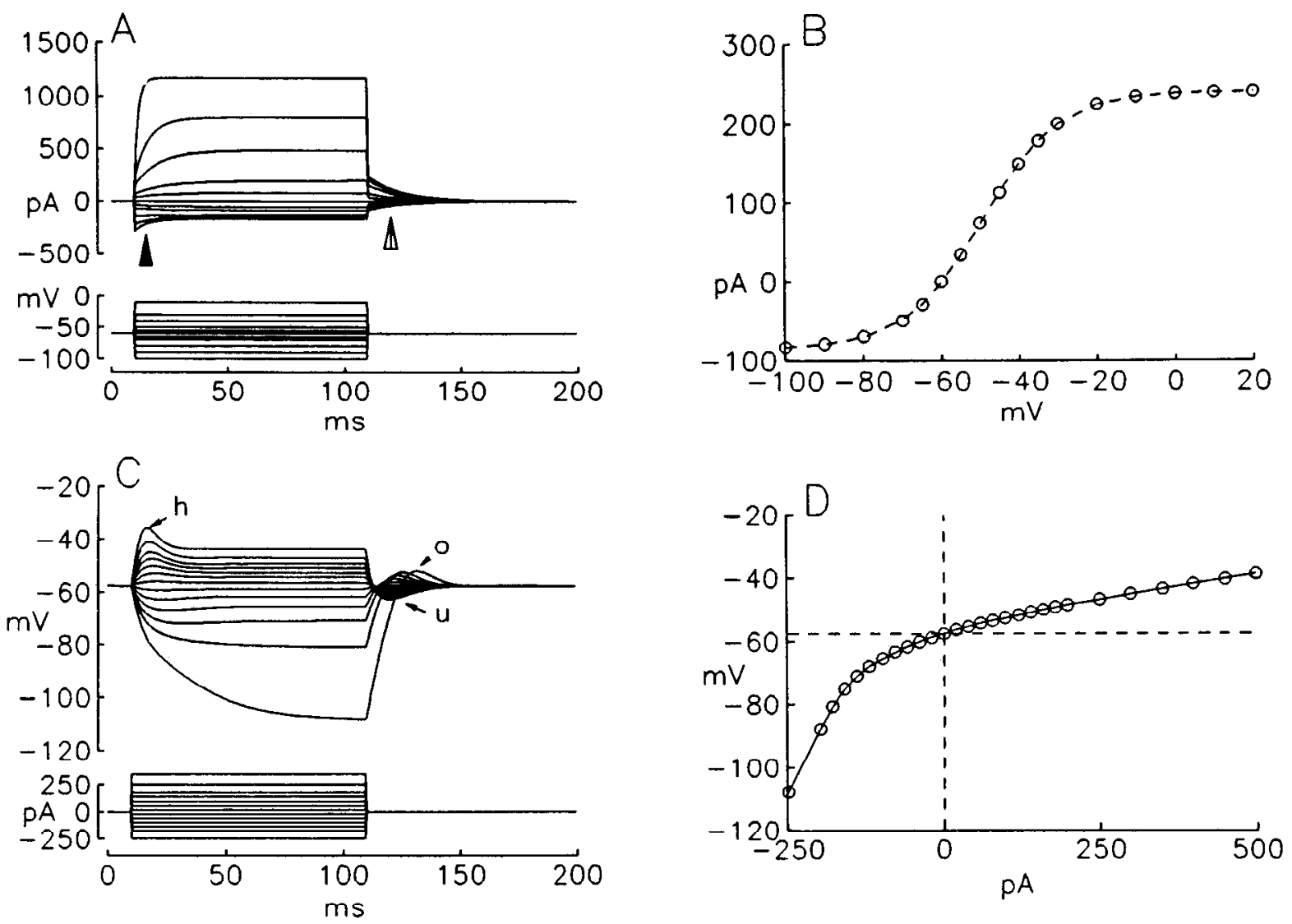

Figure 11. Model of low-threshold outward current in Type II cells. A, Currents calculated from model in voltage clamp using Equation 5. Transient inward current (solid arrowhead) and low-threshold activation characteristics of the current in Type II cells are evident. The slow tail currents following both hyperpolarizing and depolarizing commands are also evident (open arrowhead). $B$, Instantaneous current-voltage relationship (circles) determined from model data in $A$, using same methods as in Figures 4 and 7 . The dashed line is fit of Boltzmann function to points (see Eq. 4). $C$, Model responses to current steps in current clamp. The time-dependent nonlinearities caused by the low-threshold conductance are evident, including an early hump $(h)$ during depolarizing steps, and overshoots $(o)$ and undershoots $(u)$ following the end of the current step. $D$, Steadystate current-voltage relationship from current-clamp data in $C$, measured just before the end of the current step. Rectification in the relationship due to activation of the low-threshold conductance begins near $-70 \mathrm{mV}$. Similar rectification is evident in experimental data (i.e., Fig. $2 D$ ).

of the response can be adequately explained by the behavior of the low-threshold potassium current.

Figure $11 D$ shows the steady-state current-voltage relationship measured at $100 \mathrm{msec}$ from the traces in Figure $11 \mathrm{C}$. Significant rectification of the current-voltage relationship is evident. The rectification begins at a potential below rest (approximately $-70 \mathrm{mV}$ ), consistent with observations in isolated cells (Fig. 2) and in the slice (Oertel, 1983).

\section{Discussion}

These experiments demonstrate that Type I and Type II cells in the VCN possess different complements of outward currents. The Type I cells possess noninactivating outward currents that activate at membrane potentials between -40 and $-30 \mathrm{mV}$ and can be blocked by TEA, but not by 4-AP. The Type II cells possess two different noninactivating outward conductances. One activates near $-70 \mathrm{mV}$ and is nearly completely blocked by 4 mM 4-AP but is only partially blocked by $20 \mathrm{~mm}$ TEA. This conductance has slow activation and deactivation kinetics. The other conductance in Type II cells is blocked by TEA and is similar to the rapidly deactivating conductance of Type I cells. The pharmacological results and the reversal potential data suggest that these outward currents are carried primarily through potassium-selective channels.

\section{Identification of cell types}

Our recordings indicate the presence of two types of intrinsic responses in VCN neurons, in agreement with Oertel (1983). Neurons of the VCN can be divided into two broad populations based on morphology: the stellate cells and the bushy cells (Brawer et al., 1974; Cant and Morest, 1979; Lorente de No, 1981; Tolbert and Morest, 1982; Willard and Ryugo, 1983; Hackney ct al., 1990). The stellate cells receive auditory nerve inputs and other inputs on their somas and proximal dendrites in the form of bouton endings (small endings). The density of somatic input has been found to be correlated with physiologically defined subclasses and projection sites (Cant, 1981, 1982; Tolbert and Morest, 1982; Smith and Rhode, 1989). Intracellular recording and HRP marking experiments have identified stellate cells as neurons that generate highly regular spike trains in response to acoustic stimuli (Rhode et al., 1983; Rouiller and Ryugo, 1984; Smith and Rhode, 1989).

Although we did not directly identify the Type I cells that we recorded as belonging to a specific morphological population, indirect reasoning suggests that they are VCN stellate cells. In slices, cells identified by HRP injection as stellate cells were found to have the regular discharge properties associated with Type I cells (Wu and Oertel, 1984). Therefore, it is likely that 
the Type I cells in the present study were also stellate cells. A more direct proof of the origin of the Type I cell population would be desirable, however.

The other major class of VCN neuron is the bushy cell. Bushy cells have only a few thick dendrites that branch profusely a short distance from the cell body (Brawer et al., 1974; Cant and Morest, 1979; Lorente de No, 1981; Tolbert and Morest, 1982; Hackney et al., 1990). Much (but not all) of the synaptic input to these cells appears to be directed at the cell body. These cells receive their auditory nerve input via large calycoidal synapses (found on the somas of the spherical bushy cells in the anterior VCN) or via large end bulbs of Held (found on the somas of the globular bushy cells located in and around the nerve root). Bushy cells labeled with intracellular injections of HRP have bcen found to generate primary-like responses to acoustic stimuli (Rhode et al., 1983; Rouiller and Ryugo, 1984; Smith and Rhode, 1987). It is thought that the bushy cells have primarylike responses because the large auditory nerve endings provide a strong synaptic input close to the site of action potential generation, leaving little room for dendritic integration.

Intracellular recordings from HRP-labeled bushy cells in the mouse slice (Wu and Oertel, 1984) have revealed that these cells respond to depolarizing current pulses with a phasic discharge of one to three action potentials. Following this initial discharge, the cell enters a high conductance state until the applied current is terminated. These properties are very similar to the Type II cells in the present study. Thus, it is likely that our Type II cells were derived from the VCN bushy cell populations.

\section{Type I cells}

The main outward current of Type I cells appears to be carried through potassium channels with a relatively high activation threshold. The current deactivates with two time constants, one fast $(1.5 \mathrm{msec})$ and one slow $(6-18 \mathrm{msec})$. The presence of these two decay time constants may indicate the presence of two different kinds of channels with different kinetics or may represent the presence of only one channel species with multiple open states or multiple closure pathways with different rates. In two of the four cells in which the distinct rates could be determined, the fast and slow components had a different voltage dependence, with the slow component activating 12-25 mV negative to the fast component, suggesting the presence of two kinds of channels. In the remaining two cells, the two components activated at about the same potential.

The presence of two kinetically distinct outward conductances may be significant in the control of cell firing rates. The rapidly deactivating conductance should contribute primarily to the downstroke of each action potential, thereby controlling action potential width. The slowly deactivating conductance will be important in determining the duration of the spike afterhyperpolarization and therefore will affect interspike interval timing. Although the number of cells is small, we observed two groupings in the time constants of the slow conductances. Two cells had faster deactivation time constants at $-60 \mathrm{mV}(6.2$ and 7.8 $\mathrm{msec})$, whereas three cells had slower time constants $(15.4,17.2$, and $18.0 \mathrm{msec}$ ). It might be predicted that cells with different deactivation rates would exhibit different afterhyperpolarization duration and therefore different maximal driven rates for a given depolarization. The heterogeneity of Type I cell conductances is not surprising in light of the diverse interspike interval distribution and regularity functions reported for the chopper-stellate cell populations in vivo (Bourk, 1976; Young et al., 1988;
Blackburn and Sachs, 1989). Compound afterhyperpolarizations have been described for a small population of VCN Type I cells in the slice (Oertel et al., 1990). Such afterhyperpolarizations could be produced by the activation of two kinetically distinct outward currents.

The membrane conductance of Type I cells is relatively linear in the subthreshold voltage range, making these cells suited to perform a linear summation of numerous weak synaptic currents. However, two additional voltage-dependent conductances are evident in this voltage range and in the suprathreshold range that may influence the cell's discharge patterns. First, in many isolated Type I cells, there appeared to be a small noninactivating inward current in the voltage range between -60 and $0 \mathrm{mV}$; this current was particularly evident in the presence of TEA and 4-AP (i.e., Fig. 5). This current could be due to a noninactivating fraction of the rapidly inactivating sodium conductance that produces the action potential (Steinberg, 1988; see also Manis et al., 1991). It is also possible that this current is a consequence of the cell isolation procedure, as it is known that pronase, one of the enzymes used to isolate the cells, can remove sodium inactivation when applied to the interior of the cell (Armstrong et al., 1973). It seems unlikely that a significant amount of pronase entered the cells during our dissociation, since the trituration step took place in the presence of trypsin inhibitor and after the pronase was washed from the slice. Also, the noninactivating inward current was not seen in Type II cells prepared from the same tissue in the same manner. A second conductance seen in some Type I cells was a transient outward current (preliminary results are reported in Manis and Marx, 1989; Manis et al., 1991) similar to the A-current (Connor and Stcvens, 1971).

\section{Type II cells}

Our observations strongly support the hypothesis that VCN Type II cells possess two distinct outward conductances. One conductance has a high threshold $(-30 \mathrm{mV})$ and is relatively resistant to $4 \mathrm{~mm}$ 4-AP but can be blocked by $20 \mathrm{~mm}$ TEA. A rapidly deactivating tail current (time constant, $1.6 \mathrm{msec}$ ) is present that has a similar voltage dependence. Although we do not have information on the pharmacologic profile of the tail current, the similar voltage dependence of the steady-state, TEAsensitive current and the fast tail current suggests that they represent the same conductance. This high-threshold conductance is similar to the rapidly deactivating high-threshold conductance of the Type I cells.

The second conductance has a low threshold $(-70 \mathrm{mV})$ and is blocked by 4-AP but only partially by TEA. The slow tail current has a similar voltage dependence, and we suggest that these are manifestations of the same conductance. In addition, hyperpolarizations from rest to below the reversal potential produce an inward current in these cells that is also sensitive to 4-AP but not TEA, suggesting that a portion of the slow conductance is active at a holding potential of $-60 \mathrm{mV}$. The voltage-dependent features of the isolated Type II cells (both under current and voltage clamp) in this voltage regime can be reproduced in a model that presumes the existence of a single potassium conductance with first-order kinetics and a voltage dependence corresponding to that of the instantaneous tail currents. Thus, we suggest that this low-threshold, noninactivating conductance is primarily responsible for the highly rectifying current-voltage relationship of Type II cells.

In both the slice and the isolated cells, this conductance is 
partially activated at rest but turns on with sustained depolarization just slowly enough to permit a few action potentials to be generated. The cell membrane potential is then determined by an equilibrium between the injected current, the voltagedependent characteristics of the conductance, and the linear leak conductance. This equilibrium potential is depolarized to that needed for deinactivation of the sodium conductance as well as below the action potential generation threshold, and thus the cell does not fire. This conductance also generates undershoots and overshoots in the cell membrane potential following perturbations from rest. The overshoots that follow hyperpolarization sometimes result in anodal break action potentials (see Fig. 2C and Oertel, 1983).

The low-threshold conductance in the Type II VCN cells exhibits characteristics similar to some other potassium conductances in neuronal cells. One such conductance is the socalled "M-current"' ( $\Lambda$ dams et al., 1982) of sympathetic ganglion cells. The similarities between the low-threshold conductance and the M-current extend to the voltage range over which they are active, their noninactivating characteristics, and their influence on the membrane potential after perturbation in currentclamp experiments (i.e., anodal rebound responses and postdepolarization undershoots). However, the activation and deactivation kinetics of the Type II cell current are an order of magnitude faster than those described for $\mathbf{M}$-currents in either frog or rat sympathetic neurons (Adams et al., 1982; Galvan and Sedlmeir, 1984; Selyanko et al., 1990) or rat hippocampal pyramidal cells (Halliwell and Adams, 1985). The effective gating valence of the M-current was estimated to be 2.5 , which compares closely to a value of 2.4 for the low-threshold conductance in Type II cells. However, the half-activation voltage for the M-current is $-35 \mathrm{mV}$ (Adams et al., 1982), which is quite depolarized to the half-activation voltage of $-53 \mathrm{mV}$ determined for Type II cells. The half-activation voltage for the M-current in Rana pipiens was $-52 \mathrm{mV}$, although the effective gating valence was $\sim 3.6$ (Selyanko et al., 1990).

Another comparable conductance, the Shaw gene product, has been identified in Drosophila (Wei et al., 1990). This potassium channel produces a noninactivating current that first becomes visible near $-70 \mathrm{mV}$ and that is blocked more effectively by 4-AP (1-2 mM) than TEA (10 mM) (Wei et al., 1990). The resultant conductance is remarkably similar to the lowthreshold current in Type II cells.

One of the two potassium conductances characterized in guinea pig cochlear inner hair cells (IHCs) (Kros and Crawford, 1989) also is similar to the conductance in the Type II cells. The slow conductance in IHCs has a similar operating range and is more sensitive to block by 4-AP than TEA. However, two differences between the conductances are evident. First, the IHC conductance was best blocked by relatively high concentrations (15 mM) of 4-AP inside the cell, whereas the Type II cell conductance was blocked by more moderate concentrations (4 mM) of 4-AP outside the cell. Second, the slopes determined from Boltzmann fits to the two conductances are somewhat different $(\sim 3.3$ for IHCs vs. 2.4 for Type II cells).

Functional signiflcance of the low-threshold conductance in Type II cells. Bushy cells of the VCN preserve at their output the precise temporal patterns of activity of auditory nerve fibers (Goldberg and Brownell, 1973; Bourk, 1976; Sullivan and Konishi, 1984; Rhode and Smith, 1986). The bushy cells appear to have three mechanisms that are important for the retention of this information: low afferent convergence ratios (Lorente de
No, 1981; Ryugo and Fekete, 1982); strong, brief synaptic inputs (e.g., Oertel, 1983); and rapid electrical characteristics.

One of the major effects of the low-threshold conductance is to reduce the cell time constant, thereby contributing to rapid electrical characteristics and keeping synaptic events brief. Since this conductance is larger than any other in the voltage range near rest, it is of primary importance in determining the cell's time constant. Although a short resting time constant will permit the cell to be depolarized rapidly by synaptic conductances, such conductances must be large in order to generate sufficient membrane potential change against the low input resistance of the cell to initiate an action potential. Full activation of the conductance can reduce the time constant by a factor of 4-10, or from $\sim 2 \mathrm{msec}$ to perhaps as short as $0.2 \mathrm{msec}$. Such a change may occur quickly after activation of the conductance.

Our kinetic measurements were made at $22^{\circ} \mathrm{C}$, where the activation time constant of the low-threshold conductance is 13 msec at $-60 \mathrm{mV}$. However, if we assume a $Q_{10}$ of 3 for the kinetics of the conductance (Hodgkin and Huxley, 1952; Hille, 1984), the activation time constant is expected to be $2.5 \mathrm{msec}$ at $37^{\circ} \mathrm{C}$ and $-60 \mathrm{mV}$. The activation time constant will become shorter when the cell is depolarized (Fig. 10A). Thus, during an EPSP and a possible subsequent action potential, rapid and significant additional activation of the low-threshold conductance will occur, further increasing the membrane conductance and decreasing the time constant. The EPSP should then decay with a time course approaching that of the underlying synaptic conductance change. The duration of auditory nerve EPSPs in VCN bushy cells has indeed been noted to be very short $(\approx 1$ msec; Oertel, 1983). It is also likely that a rapidly desensitizing receptor (see, e.g., Tang et al., 1989; Trussell and Fischbach, 1989) could contribute to brief EPSPs. After an EPSP or action potential, the membrane conductance will take a few milliseconds to return to its resting state, so subsequent EPSPs will be reduced in amplitude.

One consequence of the brief synaptic conductance and short time constant is that the time window for successive EPSPs to sum is limited to less than $1 \mathrm{msec}$, as has been noted in in vivo recordings from some VCN cells (Romand, 1978; Smith and Rhode, 1987), as well as in vitro (Oertel, 1983, 1985). If we assume that each synaptic potential is large enough to bring the cell to threshold for an action potential, these cells should generate spike trains that are closely allied with the pattern of incoming afferent activity (Pfeiffer, 1966b). One important consequence of this is that the output of the cell will preserve the precise temporal properties of the input (such as information about the acoustic phase). On the other hand, if the synaptic potentials are subthreshold (as may be the case in globular bushy cclls; scc Smith and Rhode, 1987), then close temporal coincidence of EPSPs from at least two fibers would be necessary to produce an output.

We would predict that other cells in the auditory system that receive relatively large synaptic inputs and that may need to preserve afferent timing information, such as the principal cells of the medial nucleus of the trapezoid body (MNTB) (Morest, 1968) or neurons in the ventral nucleus of the lateral lemniscus (Adams, 1978; Willard and Ryugo, 1983; Vater and Feng, 1990) may also have this conductance. An outward rectification under current clamp that could be caused by a low-threshold conductance has been reported by Wu and Kelly (1991) and Banks and Smith (1990) for neurons of the MNTB in brain slices. This conductance might be present in other neurons where temporal 
coincidence of afferent inputs is important. One such site in the auditory system is the medial superior olive (or the avian nucleus laminaris), where the spatial location of low-frequency sounds is thought to be determined by neurons that detect binaural phase coincidence (Jeffress, 1948; Goldberg and Brown, 1969; Young and Rubel, 1973; Yin and Chan, 1988; Carr and Konishi, 1990).

\section{Appendix}

This appendix describes the equations used in the model for the lowthreshold conductance in Type II cells. Following the formulation of Hodgkin and Huxley (1952), we can describe the conductance as follows:

$$
g_{B}(V)=B_{B}(V) G_{B \max },
$$

where $g_{B}(V)$ is the conductance as a function of voltage (the subscript $B$ is used to denote the low-threshold potassium conductance in presumptive bushy (Type II) cells), $B_{B}(V)$ is the instantaneous activation state of the conductance ( 0 being fully off and 1 being fully activated), and $G_{B \max }$ is the total conductance attributed to these channels. The conductance appeared to follow first-order kinetics. Assuming that the conductance has only one closed and one open state, the instantaneous activation state at a given voltage can be computed from

$$
\frac{d B}{d t}=\alpha_{B}(1-B)-\beta_{B} B
$$

where $\alpha_{B}$ is the activation (opening) rate constant and $\beta_{B}$ is the deactivation (closing) rate constant, both of which are functions of voltage. According to standard rate theory, the voltage dependence of the rate constants can be described as an exponential function:

$$
\begin{aligned}
& \alpha_{B}(V)=\alpha_{B}(0) e^{-\left(V-V_{o}\right) K \alpha}, \\
& \beta_{B}(V)=\beta_{B}(0) e^{\left(V-V_{o}\right) K \beta},
\end{aligned}
$$

where $V_{o}$ is the half-activation (or deactivation) voltage, $K \alpha$ and $K \beta$ control the slopes of the rate functions, and $\alpha_{B}(0)$ and $\beta_{B}(0)$ control the amplitudes of the rate constants. Solving Equation $A 2$ yields an exponential function with a single relaxation time constant:

$$
\tau_{B}=\left(\alpha_{B}+\beta_{B}\right)^{-1} \text {. }
$$

The steady-state value of $B_{B}(V)$, determined from Equation $A 2$ when $d B / d t=0$, is

$$
B_{B(\infty)}=\alpha_{B} /\left(\alpha_{B}+\beta_{B}\right) .
$$

The macroscopic time constant $\tau_{B}$ and the steady-state activation parameter $B_{B(\infty)}(V)$ are measurable parameters. Then, from Equations A5 and $\mathrm{A} 6$, we can derive the rate constants $\alpha_{B}$ and $\beta_{B}$ in terms of these parameters as follows:

$$
\begin{aligned}
& \alpha_{B}(V)=B_{B(\infty)}(V) / \tau_{B}(V), \\
& \beta_{B}(V)=\left(1-B_{B(\infty)}(V)\right) / \tau_{B}(V) .
\end{aligned}
$$

The time constants $\tau_{B}(V)$ are plotted in Figure $10 A$. The rate functions of Equations $A 7$ and $A 8$ are plotted as squares and triangles in Figure $10 B$.

\section{References}

Adams JC (1978) Morphology and physiology in the ventral nucleus of the lateral lemniscus. Soc Neurosci Abstr 4:3.

Adams PR, Brown DA, Constanti A (1982) M-Currents and other potassium currents in bullfrog sympathetic neurons. J Physiol (Lond) 330:537-572.

Akaike N, Kaneda M, Hori N, Krishtal OA (1988) Blockade of $N$-methyl-D-aspartate response in enzyme treated rat hippocampal neurons. Neurosci Lett 87:75-79.

Armstrong CM, Bezanilla F, Rojas E (1973) Destruction of sodium conductance inactivation in squid axons perfused with pronase. J Gen Physiol 62:375-391.

Bader CR, Bertrand D, Dupin E (1985) Voltage-dependent potassium currents in developing neurones from quail mesencephalic neural crest. J Physiol (Lond) 366:129-151.

Banks MI, Smith PH (1990) Intracellular recordings from cells in the rat superior olivary complex (SOC) labelled with biocytin. Soc Neurosci Abstr 16:722.

Bertrand D, Bader CR (1986) DATAC: a multipurpose biological data analysis program based on a mathematical interpreter. Int J Biomed Comput 18:193-202.

Blackburn CB, Sachs MB (1989) Classification of unit types in the anteroventral cochlear nucleus: PST histograms and regularity analysis. J Neurophysiol 62:1303-1329.

Bourk TR (1976) Electrical responses of neural units in the anteroventral cochlear nucleus of the cat. PhD thesis, Massachusetts Institute of Technology.

Brawer JR, Morest DK (1975) Relations between auditory nerve endings and cell types in the cat's anteroventral cochlear nucleus seen with the Golgi method and Nomarski optics. J Comp Neurol 160: 491-506.

Brawer JR, Morest DK, Kane EC (1974) The neuronal architecture of the cochlear nucleus of the cat. J Comp Neurol 155:251-300.

Cant NB (1981) The fine structure of two types of stellate cells in the anterior division of the anteroventral cochlear nucleus of the cat. Neuroscience 6:2643-2655.

Cant NB (1982) Identification of cell types in the antcroventral cochlear nucleus that project to the inferior colliculus. Neurosci Lett 32: 241-246.

Cant NB, Morest DK (1979) Organization of the neurons in the anterior division of the anteroventral cochlear nucleus. Light microscopic observations. Neuroscience 4:1909-1923.

Carr CE, Konishi M (1990) A circuit for detection of interaural time differences in the brainstem of the barn owl. J Neurosci 10:32273246.

Connor JA, Stevens CF (1971) Voltage clamp studies of a transient outward membrane current in gastropod neural somata. J Physiol (Lond) 312:21-30.

Ehrenstein G, Blumenthal R, Latorre R, Lecar H (1974) Kinetics of the opening and closing of individual excitability-inducing material channels in a lipid bilayer. J Gen Physiol 63:707-721.

Fekete DM, Rouiller EM, Liberman MC, Ryugo DK (1984) The central projections of intracellularly labeled auditory nerve fibers in cats. J Comp Neurol 229:432-450.

Feldman ML, Harrison JM (1969) The projection of the acoustic nerve to the ventral cochlear nucleus of the rat. A Golgi study. J Comp Neurol 137:267-294.

Finkel AS, Redman SJ (1985) Optimal voltage clamping with a single electrode. In: Voltage and patch clamping with microelectrodes (Smith TG, Lecar H, Redman SJ, Gage PW, eds), pp 95-120. Bethesda, MD: American Physiological Society.

Galvan M, Sedlmeir C (1984) Outward currents in voltage-clamped rat sympathetic neurones. J Physiol (Lond) 356:115-133.

Goldberg JM, Brown PB (1969) Response of binaural neurons of dog superior olivary complex to dichotic tonal stimuli: some physiological mechanisms of sound localization. J Neurophysiol 32:613-636.

Goldberg JM, Brownell WE (1973) Discharge characteristics of neurons in anteroventral and dorsal cochlear nuclei of cat. Brain Res 64 35-54.

Gray R, Johnston D (1985) Rectification of single GABA-gatcd chloride channels in adult hippocampal neurons. J Neurophysiol 54:134142.

Hackney CM, Osen KK, Kolston J (1990) Anatomy of the cochlear nuclear complex of guinea pig. Anat Embryol 182:123-149.

Halliwell JV, Adams PR (1982) Voltage-clamp analysis of muscarinic excitation in hippocampal neurons. Brain Res 250:71-92.

Hamill OP, Marty A, Neher E, Sakmann B, Sigworth FJ (1981) Improved patch-clamp techniques for high-resolution current recording from cells and cell-free membrane patches. Pfluegers Arch 391:85100.

Harrison JM, Irving R (1966) The organization of the posteroventral cochlear nucleus in the rat. J Comp Neurol 126:391-402.

Hille B (1984) Ionic channels of excitable membranes. Sunderland, MA: Sinauer.

Hodgkin AL, Huxley AF (1952) A quantitative description of membrane current and its application to conduction and excitation in nerve. J Physiol (Lond) 117:500-544.

Jeffress LA (1948) A place theory of sound localization. J Comp Physiol Psychol 41:35-39.

Kay AR, Wong RKS (1986) Isolation of neurons suitable for patch clamping from adult mammalian central nervous system. J Neurosci Methods 16:227-238.

Kolb H-A (1990) Potassium channels in excitable and non-excitable cells. Rev Physiol Biochem Pharmacol 115:52-91. 
Kros CJ, Crawford AC (1990) Potassium currents in inner hair cells isolated from the guinea-pig cochlea. J Physiol (Lond) 421:263-291.

Lorente de No R (1981) The primary acoustic nuclei. New York: Raven.

Manis PB (1989) Responses to parallel fiber stimulation in the guinea pig dorsal cochlear nucleus in vitro. J Neurophysiol 61:1151-1166.

Manis PB, Bertrand D (1989) A fast inexpensive analog-to-digital converter board for IBM PC-AT or compatible. J Neurosci Methods 30:41-54.

Manis PB, Marx SO (1989) Voltage clamp studies of isolated ventral cochlear nucleus neurons. Soc Neurosci Abstr 15:744.

Manis PB, Marx SO, White JA (1991) Integrative mechanisms of ventral cochlear nucleus stellate cells: membrane conductances and electrotonic structure. In: Cochlear nucleus structure and function: relation to modeling (Ainsworth WA, ed), in press. London: JAI.

Marty A, Neher E (1983) Tight-seal whole-cell recording. In: Single channel recording (Sakmann B, Neher E, eds), pp 107-122. New York: Plenum.

Morest DK (1968) The collateral system of the medial nucleus of the trapezoid body of the cat, its neuronal architecture and relation to the olivocochlear bundle. Brain Res 9:288-311.

Numann RE, Wadman WJ, Wong RKS (1987) Outward currents of single hippocampal cells obtained from the adult guinea-pig. J Physiol (Lond) 393:331-353.

Oertel D (1983) Synaptic responses and electrical properties of cells in brain slices of the mouse anteroventral cochlear nucleus. J Neurosci 3:2043-2053.

Oertel D (1985) Use of brain slices in the study of the auditory system: spatial and temporal summation of synaptic inputs in the anteroventral cochlear nucleus of the mouse. J Acoust Soc Am 78:328-333.

Oertel D, Wu SH, Garb MW, Dizack C (1990) Morphology and physiology of cells in slice preparations of the posteroventral cochlear nucleus of mice. J Comp Neurol 295:136-154.

Osen KK (1970) Course and termination of the primary afferents in the cochlear nuclei of the cat. Arch Ital Biol 108:21-51.

Pfeiffer RR (1966a) Classification of response patterns of spike discharges for units in the cochlear nucleus: tone burst stimulation. Exp Brain Res 1:220-235.

Pfeiffer RR (1966b) Anteroventral cochlear nucleus: waveforms of extracellularly recorded spike potentials. Science 154:667-668.

Rhode WS, Smith PH (1986) Encoding timing and intensity in the ventral cochlear nucleus of the cat. J Neurophysiol 56:261-286.

Rhode WS, Ocrtel D, Smith PH (1983) Physiological response properties of cells labeled intracellularly with horseradish peroxidase in cat ventral cochlear nucleus. J Comp Neurol 213:448-463.

Romand R (1978) Survey of intracellular recording in the cochlear nucleus of the cat. Brain Res 148:43-65.

Rouiller EM, Ryugo DK (1984) Intracellular marking of physiologically characterized cells in the ventral cochlear nucleus of the cat. J Comp Neurol 225:167-186.

Rouiller EM, Cronin-Schrieber R, Fekete DM, Ryugo DK (1986) The central projections of intracellularly labeled auditory nerve fibers: an analysis of terminal morphology. J Comp Neurol 249:261-278.

Ryugo DK, Fekete DM (1982) Morphology of primary axosomatic endings in the anteroventral cochlear nucleus of the cat: a study of the endbulbs of Held. J Comp Neurol 210:239-257.
Selyanko AA, Smith PA, Zidichouski JA (1990) Effects of muscarine and adrenaline on neurones from Rana pipiens sympathetic ganglia. J Physiol (Lond) 425:471-500.

Smith PH, Rhode WS (1987) Characterization of HRP-labeled globular bushy cells in the cat anteroventral cochlear nucleus. J Comp Neurol 266:360-375.

Smith PH, Rhode WS (1989) Structural and functional properties distinguish two types of multipolar cells in the ventral cochlear nucleus. J Comp Neurol 282:595-616.

Stanfield PR (1983) Tetraethylammonium ions and the potassium permeability of excitable cells. Rev Physiol Biochem Pharmacol 97: $1-67$.

Steinberg IZ (1988) Computer simulations of the effect of non-inactivating sodium channels on the electric behavior of excitable cells. J Theor Biol 133:193-214.

Sullivan WE, Konishi M (1984) Segregation of stimulus phase and intensity coding in the cochlear nucleus of the barn owl. J Neurosci 4:1787-1799.

Tang C-M, Dichter M, Morad M (1989) Quisqualate activates a rapidly inactivating high conductance ionic channel in hippocampal neurons. Science 243:1474-1477.

Tolbert LP, Morest DK (1982) The neuronal architecture of the anteroventral cochlear nucleus of the cat in the region of the cochlear nerve root: Golgi and Nissl methods. Neuroscience 7:3013-3030.

Trussell LO, Fischbach GD (1989) Glutamate receptor desensitization and its role in synaptic transmission. Neuron 3:209-218.

Vater M, Feng AS (1990) Functional organization of ascending and descending connections of the cochlear nucleus of horseshoe bats. J Comp Neurol 292:373-395.

Wei A, Covarrubias M, Butler A, Baker K, Pak M, Salkoff L (1990) $\mathrm{K}^{+}$current diversity is produced by an extended gene family conserved in Drosophila and mouse. Science 248:599-602.

Willard JM, Ryugo DK (1983) Anatomy of the central auditory system. In: The auditory psychobiology of the mouse (Willot JF, ed), pp 201-304. Springfield, IL: Thomas.

Wu SH, Kelly JB (1991) Physiological properties of neurons in the mouse superior olive: membrane characteristics and postsynaptic responses studied in vitro. J Neurophysiol 65:230-246.

Wu SH, Oertel D (1984) Intracellular injection with horseradish peroxidase of physiologically characterized stellate and bushy cells in slices of mouse anteroventral cochlear nucleus. J Neurosci 4:15771588.

Yavin E, Yavin Z (1974) Attachment and culture of dissociated cells from rat embryo cerebral hemispheres on polylysine coated surfaces. J Cell Biol 62:540-546.

Yin TC, Chan JCK (1988) Neural mechanisms underlying interaural time sensitivity to tones and noise. In: Auditory function (Edleman GM, Gall WE, Cowan, WM, eds), pp 385-420. New York: Wiley.

Young ED, Robert JM, Shofner WP (1988) Regularity and latency of units in ventral cochlear nucleus: implications for unit classification and generation of response properties. J Neurophysiol 60:1-29.

Young SR, Rubel EW (1983) Frequency-specific projections of individual neurons in chick brainstem auditory nuclei. J Neurosci 3:13731378. 